4 norden 



\section{Nordic Environmental Valuation Database}

Slutrapport till Nordiska Ministerrådets miljö- och ekonomigrupp

Ståle Navrud, SWECO Grøner AS; Åsa Soutukorva, Enveco Miljöekonomi AB; Tore Söderqvist, Enveco Miljöekonomi AB;

Yngve Træedal, SWECO Grøner AS 
Nordic Environmental Valuation Database

Slutrapport till Nordiska Ministerrådets miljö- och ekonomigrupp

TemaNord 2007:518

(C) Nordiska ministerrådet, Köpenhamn 2007

ISBN 978-92-893-1466-4

Tryck: Ekspressen Tryk \& Kopicenter

Upplaga: Print on Demand

Publikationen kan beställas på www.norden.org/order. Fler publikationer på

www.norden.org/publikationer

Nordiska ministerrådet

Store Strandstræde 18

DK-1255 Köpenhamn K

Telefon $(+45) 33960200$

Fax (+45) 33960202

www.norden.org

\section{Nordiska rådet}

Store Strandstræde 18

DK-1255 Köpenhamn K

Telefon (+45) 33960400

Fax (+45) 33111870

\section{Det nordiska samarbetet}

Det nordiska samarbetet är ett av världens mest omfattande regionala samarbeten. Det omfattar Danmark, Finland, Island, Norge och Sverige samt de självstyrande områdena Färöarna, Grönland och Åland.

Det nordiska samarbetet är politiskt, ekonomiskt och kulturellt förankrat och är en viktig partner i europeiskt och internationellt samarbete. Den nordiska gemenskapen arbetar för ett starkt Norden i ett starkt Europa.

Det nordiska samarbetet vill styrka nordiska och regionala intressen och värderingar i en global omvärld. Gemensamma värderingar länderna emellan bidrar till att stärka Nordens ställning som en av världens mest innovativa och konkurrenskraftiga regioner. 


\section{Indholdsfortegnelse}

Om projektet och dess resultat................................................................................. 7

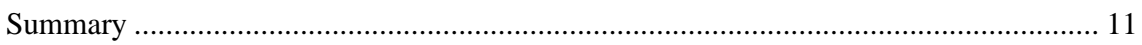

Appendix 1. Verdsettning av miljøgoder og retningslinjer for benefit transfer ................ 15

A1.1 Metodikk for verdsetting av miljøgoder ...................................................... 15

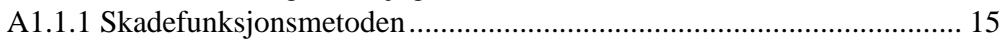

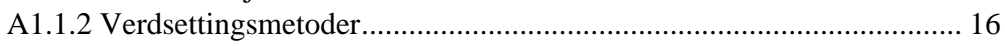

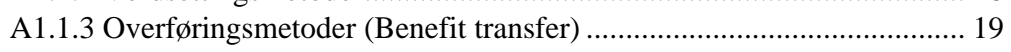

A1.2 Retningslinjer for benefit transfer................................................................ 20

A1.2.1 Steg 1 - Identifiser miljøendringen som ønskes verdsatt på

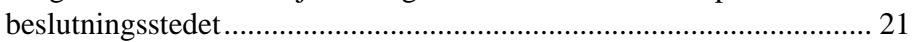

A1.2.2 Steg 2 - Identifisere den berørte populasjonen på beslutningssteget... 21

A1.2.3 Steg 3 - Utfør en litteraturgjennomgang for å identifisere relevante primære verdsettingsstudier ....

A1.2.4 Steg 4 - Gjennomgå relevansen og kvaliteten i

verdsettingsestimatene fra studien for mulig benefit transfer................ 23

A1.2.5 Steg 5 - Velg ut og oppsummer tilgjengelig data fra studiestedet........ 24

A1.2.6 Steg 6 - Overfør verdier fra studie- til beslutningssted ....................... 25

A1.2.7 Steg 7 - Kalkulere total nytte eller kostnader.................................... 27

A1.2.8 Steg 8 - Usikkerhet og akseptabel overføringsfeil ............................... 28

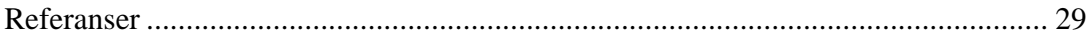

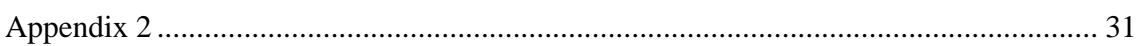

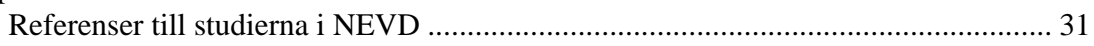





\section{Om projektet och dess resultat}

Den här rapporten handlar om resultaten av projektet Nordic Environmental Valuation Database (NEVD). Projektets mål var att skapa en offentlig databas som innehåller resultat från nordiska miljövärderingsstudier. Projektet genomfördes under april-december 2006 av Enveco Miljöekonomi AB, MTT Agrifood Research Finland och SWECO Grøner AS, se även tabell 1 .

Tabell 1. Projektets utförare.

\begin{tabular}{ll}
\hline Organisation & Deltagande medarbetare inklusive projektledare \\
\hline $\begin{array}{l}\text { Enveco Miljöekonomi AB } \\
\text { (www.enveco.se) }\end{array}$ & Tore Söderqvist, Åsa Soutukorva \\
$\begin{array}{l}\text { MTT Agrifood Research Finland } \\
\text { (www.mtt.fi) }\end{array}$ & Eija Pouta, Janne Vesterinen \\
$\begin{array}{l}\text { SWECO Grøner AS } \\
\text { (www.sweco.no) }\end{array}$ & Ståle Navrud, Kristian Hall, Jan Atle Liodden, Yngve Trædal \\
\hline
\end{tabular}

Bakgrunden till projektet är behovet av att undersöka om föreslagna eller genomförda projekt i samhället är samhällsekonomiskt lönsamma eller inte. Ekonomers standardverktyg för att göra detta är kostnadsnyttoanalys (cost-benefit analysis, CBA). För att en CBA av ett projekt ska bli rättvisande bör den inkludera de samhällsekonomiska konsekvenserna av projektets effekter på miljön. Att väga in miljöeffekter i CBA är dock eftersatt, såväl i de nordiska länderna som i övriga världen. Det finns dock en ökande politisk insikt om vikten av att ta hänsyn till vilket ekonomiskt värde som miljöförbättringar har respektive vilken ekonomisk skada som miljöförsämringar medför. Information om sådana ekonomiska värden och skador finns att tillgå i miljövärderingsstudier. För att göra denna information tillgänglig på ett praktiskt sätt krävs dock sammanställningar av studiernas resultat. Sammanställningar i form av databaser kan utgöra grunden för ett kostnadseffektivt sätt att genomföra en CBA som inkluderar miljöeffekter, och ofta kan det vara den enda möjligheten. Några andra fördelar med databaser är:

- ökad kunskap om existerande studier, aktuella frågor samt metodutveckling.

- $\quad$ stöd för värdeöverföring (benefit transfer), det vill säga när värderingsresultat generaliseras från sitt ursprungliga sammanhang till andra sammanhang.

- $\quad$ underlättande för skapande av nätverk mellan personer i Norden som är intresserade av frågor relaterade till värdering och CBA. 
För närvarande finns ett antal databaser att tillgå, bland annat den främst nordamerikanska Environmental Valuation Reference Inventory (EVRI, www.evri.ca), den australiska Environmental Valuation Database (ENVALUE, www.epa.nsw.gov.au/envalue) och den svenska Valuation Study Database for Environmental Change in Sweden (ValueBase ${ }^{\mathrm{SWE}}$, www.beijer.kva.se/valuebase.htm), men det fanns före det här projektet ingen samlad databas för nordiska miljövärderingsstudier.

Projektet genomfördes genom att samla in information om nordiska värderingsstudier och beskriva dem med samma variabler som ingår i EVRI. Att använda EVRI som en modell är ett naturligt val, eftersom EVRI är den största webbaserade miljövärderingsdatabasen. Även om innehållet i EVRI domineras av nordamerikanska värderingsstudier har den bedömts vara lämplig för europeiska studier. Dessutom är EVRI:s och ValueBase $^{\mathrm{SWE}}$ :s beskrivningar av studier likartade.

Tack vare samarbete med EVRI har data om nordiska miljövärderingsstudier under projektet matats in i EVRI med hjälp av EVRI:s "capture"-funktion. Information om de nordiska studierna har EVRI sedan gjort tillgänglig genom ett utdrag av EVRI i form av Excel-filen NEVD.xls. Filen innehåller information om totalt 192 nordiska värderingsstudier, varav 25 danska, 41 finska, 2 isländska, 37 norska och 60 svenska. De återstående 27 är studier som gäller flera länder, däribland minst ett nordiskt land. 79 av de 192 studierna fanns med i EVRI vid projektets början och information om 113 studier matades in i EVRI inom ramen för projektet, se tabell 2. Flertalet (ca 75 \%) av de 192 studierna har använt sig av en eller flera scenariometoder (stated preferences methods) för att genomföra miljövärderingen.

Tabell 2. Nordiska värderingsstudier i EVRI före och efter projektet.

\begin{tabular}{lccc}
\hline Land & $\begin{array}{c}\text { Antal studier i EVRI före } \\
\text { projektets början enligt } \\
\text { NEVD.xls }\end{array}$ & $\begin{array}{c}\text { Antal inlagda studier } \\
\text { under projektet enligt } \\
\text { NEVD.xls }\end{array}$ & $\begin{array}{c}\text { Totalt antal studier i } \\
\text { NEVD.xls }\end{array}$ \\
\hline Danmark & 9 & 16 & 25 \\
Finland & 12 & 29 & 41 \\
Island & 0 & 2 & 2 \\
Norge & 5 & 32 & 37 \\
Sverige & 29 & 31 & 60 \\
Studier som gäller & & & \\
flera länder, däribland & 24 & 3 & 27 \\
minst ett nordiskt land & 79 & 113 & 192 \\
Summa & & & \\
\hline
\end{tabular}

I EVRI och därmed även i NEVD finns de hittills mest kompletta sammanställningarna av nordiska miljövärderingsstudier. När det gäller svenska miljövärderingsstudier bör det noteras att NEVD.xls inte innehåller alla studier som ingår i den svenska databasen ValueBase ${ }^{\mathrm{SWE}}$. Detta beror dels på tidsrestriktioner och dels en prioritering av de studier i ValueBase ${ }^{\mathrm{SWE}}$ som har bedömts vara av hög kvalitet. $\AA$ andra sidan innehåller NEVD.xls ett antal nya svenska värderingsstudier som tillkommit efter upprättandet av ValueBase ${ }^{\mathrm{SWE}}$. 
Filen NEVD.xls innehåller även en manual för NEVD i form av en genomgång av vilka olika typer av information som finns i databasen. I EVRI beskrivs värderingsstudier av ett antal datafält. I NEVD.xls beskrivs de nordiska värderingsstudierna med kolumner som överensstämmer med dessa datafält. Datafälten kan indelas i följande sex kategorier, och manualen i filen beskriver dem i mer detalj:

1. Bibliografisk information (study reference)

2. Studieområde och population (study area and population characteristic)

3. Typ av värderad miljö (environmental focus of study)

4. Värderingsmetod (study methods)

5. Skattade värden (estimated values)

6. Sammanfattning (abstract)

Den här slutrapporten består i övrigt av följande två appendix:

- En introduktion till metoder för miljövärdering och en vägledning till hur värdeöverföringar (benefit transfers) bör göras.

- En referenslista till alla studier som finns med i NEVD.

Utgångspunkten för appendix 1 om miljövärderingsmetoder och värdeöverföringar är att tre grundläggande redskap måste finnas tillgängliga för att värdeöverföringar ska kunna genomföras och vara giltiga: i) Databas(er) med miljövärderingsstudier, ii) riktlinjer för att bedöma kvaliteten hos värderingsstudier, och iii) metoder och riktlinjer för att utföra värdeöverföringar. De här redskapen finns nu tillgängliga på följande sätt. För det första finns nordiska miljövärderingsstudier sammanställda i EVRI och NEVD. För det andra har Naturvårdsverket i Sverige utgivit ett instrument för att bedöma kvaliteten hos miljövärderingsstudier (Soutukorva och Söderqvist, 2005). För det tredje beskrivs värdeöverföringsmetoder och riktlinjer för värdeöverföring i appendix 1 , som är baserat på en rapport till Miljøstyrelsen i Danmark (Navrud, 2006).

Värdeöverföringsmetoder kan indelas i tre huvudtyper: i) överföring av enhetsvärden och ii) överföring av värderingsfunktioner. Gemensamt för värdeöverföringen är att värderingsresultat generaliseras från en existerande värderingsstudie (study site) till en ny policysituation (policy site). Överföring av enhetsvärden bygger på att skatta totalnyttan för den nya policysituationen genom att aggregera befintliga värden uttryckta per enhet. De här enhetsvärdena härleds från den existerande studien. Vid överföring av värderingsfunktioner används en värderingsfunktion från den existerande värderingsstudien. Den nya policysituationen beskrivs med hjälp av funktionens förklarande variabler och sedan kan funktionen användas för att skatta enhetsvärden och totalvärden som är giltiga för den nya policysituationen. En annan värderingsfunktionsansats är meta- 
analys, som går ut på att använda regressionsanalys för att skatta hur betalningsviljan för en viss miljövara varierar med egenskaperna hos varan, populationen och de värderingsmetoder som har använts. Enskilda data alternativt resultat från befintliga värderingsstudier om miljövaran ifråga används som observationer i regressionsmodellen.

Med Navrud (2006) som utgångspunkt rekommenderar vi följande tillvägagångssätt i åtta steg för genomförande av värdeöverföringar:

1. Identifiera den miljöförändring som ska värderas inom ramen för den nya policysituationen

I. Typ av miljövara

II. Beskriv utgångsläge, omfattning och riktning av miljöförändringen

2. Identifiera vilken population som påverkas av den nya policysituationen

3. Gör en litteraturgenomgång för att identifiera lämpliga existerande värderingsstudier att utgå ifrån

4. Bedöm om den existerande värderingsstudien (eller studierna) är relevant och lämplig att använda för värdeöverföring

I. Vetenskapligt riktig; felaktigheter och begränsningar hos den existerande studiens fortplantar sig till värdeöverföringen

II. Relevans; den existerande studien bör vara likartad och möjlig att tillämpa på den nya policysituationen

III. Rikedom på detaljer; den existerande studien bör innefatta ett detaljrikt datamaterial och vara rik på information om studien och studiens sammanhang

5. Välj och sammanfatta de data som är tillgängliga från den existerande studien

6. Överför värdeskattningar från den existerande studien till den nya policysituationen

I. Bestäm vilken enhet som ska överföras

II. Bestäm metod för rumslig överföring

III. Bestäm metod för tidsmässig överföring

7. Beräkna totalnytta eller kostnader

8. Identifiera osäkerheten och definiera vad som kan anses vara acceptabla överföringsfel

\section{Referenser}

Navrud, S. 2006. Practical Tools for Benefit Transfer in Denmark - Guidelines and an Example. E-CO Tech rapport på uppdrag från Miljøstyrelsen Danmark.

Soutukorva, Å., Söderqvist, T. 2005: Kvalitetskriterier för ekonomiska miljövärderingsstudier. Naturvårdsverket, Stockholm. ISBN 91-620-1247-9.

http://www.naturvardsverket.se/bokhandeln/pdf/620-1247-9.pdf 


\section{Summary}

This report is about the results of the project Nordic Environmental Valuation Database (NEVD). The aim of the project was to create a public database containing results from Nordic environmental valuation studies. The project was carried out during April-December 2006 by Enveco Miljöekonomi AB, MTT Agrifood Research Finland och SWECO Grøner AS, see also table 1 .

Table 1. Project team.

\begin{tabular}{ll}
\hline Organization & Participating staff members including project leader \\
\hline $\begin{array}{l}\text { Enveco Miljöekonomi AB } \\
\text { (www.enveco.se) }\end{array}$ & Tore Söderqvist, Åsa Soutukorva \\
$\begin{array}{l}\text { MTT Agrifood Research Finland } \\
\text { (www.mtt.fi) }\end{array}$ & Eija Pouta, Janne Vesterinen \\
$\begin{array}{l}\text { SWECO Grøner AS } \\
\text { (www.sweco.no) }\end{array}$ & $\begin{array}{l}\text { Ståle Navrud, Kristian Hall, Jan Atle Liodden, Yngve } \\
\text { Trædal }\end{array}$ \\
\hline
\end{tabular}

The background to the project is the fact that increased use of environmental values in strategic decisions, cost-benefit analysis (CBA) and Natural Resource Damage Assessments (NRDA) have greatly increased the demand for extensive databases and guidelines for transfer of environmental values both in time and space. Limited time and resources for these analyses often excludes new primary valuation studies, and leaves us with benefit transfer as the only option. The challenge is then to fully utilize the existing valuation studies in these benefit transfer exercises.

Such utilization is greatly facilitated by databases containing information on existing valuation studies. There are at present a number of databases available, for example the primarily North American The Environmental Valuation Reference Inventory (EVRI, www.evri.ca), the Australian The Environmental Valuation Database (ENVALUE, www.epa .nsw.gov.au/envalue) and the Swedish Valuation Study Database for Environmental Change in Sweden (ValueBase ${ }^{\mathrm{SWE}}$, www.beijer.kva.se/value base.htm), but there was no database for Nordic environmental valuation studies before this project.

The project was carried out by collecting information on Nordic valuation studies and describing them with the same variables that are used in EVRI. Using EVRI as a model was judged to be a reasonable choice, because EVRI is the largest web-based valuation study database.

A cooperative agreement with EVRI made it possible for the project to enter data on Nordic valuation studies directly into EVRI by using EVRI's “capture module". When the data entering stage of the project was finalized, EVRI extracted information on the Nordic studies into the 
Excel file NEVD.xls (requires Excel 2003 for full functionality). This file contains information on 192 Nordic valuation studies, of which 25 are studies from Denmark, 41 from Finland, 2 from Iceland, 37 from Norway and 60 from Sweden. The remaining 27 studies are multi-country studies including at least one Nordic country. 79 of the 192 studies were included in EVRI already before the project started, and information on 113 studies was entered into EVRI during the project, see table 2. The great majority (about 75\%) of the 192 studies has used one or several stated preferences methods for carrying out the environmental valuation.

Table 2. Nordic valuation studies in EVRI before and after the project.

\begin{tabular}{lccc}
\hline Country & $\begin{array}{c}\text { Number of studies in } \\
\text { EVRI before the project } \\
\text { according to NEVD.xls }\end{array}$ & $\begin{array}{c}\text { Number of studies } \\
\text { entered into EVRI during } \\
\text { the project according to } \\
\text { NEVD.xls }\end{array}$ & $\begin{array}{c}\text { Total number of } \\
\text { studies in NEVD.xls }\end{array}$ \\
\hline Denmark & 9 & 16 & 25 \\
Finland & 12 & 29 & 41 \\
Iceland & 0 & 2 & 2 \\
Norway & 5 & 32 & 37 \\
Sweden & 29 & 31 & 60 \\
Multi-country studies & 24 & 3 & 27 \\
Sum & 79 & 113 & 192 \\
\hline
\end{tabular}

EVRI and thus also NEVD constitute the so far most complete compilations of Nordic environmental valuation studies. For the case of Swedish environmental valuation studies, it should be noted that NEVD does not contain all studies that are included in the Swedish database ValueBase ${ }^{S W E}$. This is partly because of time restrictions for the NEVD project and partly because of the project put priority to those studies in ValueBase ${ }^{\mathrm{SWE}}$ that were judged to be of good quality. It should also be noted that NEVD includes a number of new Swedish valuation studies that were published after ValueBase ${ }^{\mathrm{SWE}}$ was set up.

The file NEVD.xls also contains a guide to the types of data found in the database. In EVRI, valuation studies are described by a number of data fields, and these fields correspond to the columns that describe the Nordic environmental valuation studies in the Excel file. The data fields in EVRI concern the following categories of information, and the guide included in the file describes them in some detail:

1. Study reference

2. Study area and population characteristic

3. Environmental focus of study

4. Study methods

5. Estimated values

6. Abstract

Besides an introduction, this report consists of the following two appendices: 
1. An introduction to methods for environmental valuation and guidelines for performing benefit transfer.

2. A list of references to all studies included in NEVD.

As to the first appendix on valuation methods and benefit transfer, there are three basic requisites for such transfers to be valid: i) Database of environmental valuation studies, ii) Guidelines for judging the quality of valuation studies, and iii) Methods and guidelines for performing the benefit transfer exercise. This guide deals with all three issues. First, as explained above, Nordic valuation studies have been captured in EVRI and are available both in this database and in a separate spreadsheet database with Nordic studies only, i.e. the Excel file NEVD.xls. Second, the Swedish Environmental Protection Agency (Naturvårdsverket) has prepared a checklist for assessing the quality of environmental valuation studies (Söderqvist and Soutukorva, 2006) Third, in appendix 1 of this report, the available benefit transfer methods are described, and guidelines for benefit transfer provided, based on a report to the Danish Environmental Protection Agency (Navrud, 2006).

Benefit transfer methods can be divided into two major types: i) unit value transfer and ii) value function transfer. Unit value transfer methods estimate total benefits at the policy site by aggregating existing standard values per unit. These values are derived from study site data. In value function transfer methods, estimator models derived from study site data are used with explanatory variables collected at the policy site to estimate both value per unit and total units. Another value function approach is meta-analysis where a regression analysis is conducted to analyse how willingness to pay for a particular environmental good varies with characteristics of the good, affected population and the valuation methodology. Previous valuation studies for similar types of goods are used as observations in the regression model.

Based on Navrud (2006), we have identified the following 8-step guideline for benefit transfer:

1. Identify the change in the environmental good to be valued at the policy site

I. Type of environmental good

II. Describe baseline, magnitude and direction of change in environmental quality

2. Identify the affected population at the policy site

3. Conduct a literature review to identify relevant primary studies

4. Assess the relevance and quality of study site values for transfer

I. Scientific soundness; the transfer estimates are only as good as the methodology and assumptions employed in the original studies 
II. Relevance; primary studies should be similar and applicable to the "new" context

III. Richness in detail; primary studies should provide a detailed dataset and accompanying information

5. Select and summarize the data available from the study site(s)

6. Transfer value estimate from study site(s) to policy site

I. Determine the transfer unit

II. Determine the transfer method for spatial transfer

III. Determine the transfer method for temporal transfer

7. Calculate total benefits or costs

8. Identify the uncertainty and define acceptable transfer errors

\section{Referenser}

Navrud, S. 2006. Practical Tools for Benefit Transfer in Denmark - Guidelines and an Example. E-CO Tech report for the Danish Environmental Protection Agency.

Söderqvist, T., Soutukorva, Å., 2006. An Instrument for Assessing the Quality of Environmental Valuation Studies. Swedish Environmental Protection Agency, Stockholm. ISBN 91-620-1252-5. http://www.naturvardsverket.se/bokhandeln/pdf/620-1252-5.pdf. 


\section{Appendix 1. Verdsettning av miljøgoder og retningslinjer for benefit transfer}

av Yngve Trcedal och Ståle Navrud, SWECO Grøner

\section{A1.1 Metodikk for verdsetting av miljøgoder}

Vi vil i dette kapittelet gå i gjennom «state-of-the-art» for metoder som blir brukt innen miljøøkonomi for å gi anslag for samfunnets kostnader ved miljøskader (og samfunnsøkonomisk nytte av miljøforbedringer).

\section{A1.1.1 Skadefunksjonsmetoden}

Skadefunksjonsmetoden benyttes for å komme frem til monetære verdier for miljøskader til å kalkulere eksterne kostnader. Eksterne kostnader er kostnader av produksjon og/eller forbruk av en vare/tjeneste som påføres andre produsenter og/eller forbrukere uten at de ytes full kompensasjon for dette av dem som skaper kostnadene. Et eksempel er utslipp av forurensende stoffer av produksjon av en vare, og hvor kostnadene ved denne forurensningen ikke reflekteres i markedsprisen på varen. Dermed oppstår det avvik mellom det som er bedriftsøkonomisk lønnsom produksjon av varen og det som er samfunnsøkonomisk lønnsomt (dvs. lønnsomt for alle produsenter og forbrukere samlet sett), og en vil da produsere for mye av den forurensende varen. For å skape samsvar mellom det som er bedriftsøkonomisk lønnsomt og samfunnsøkonomisk lønnsomt må vi internalisere eksterne kostnader, dvs. bruke ulike typer virkemidler for å ta disse kostnadene inn i regnskapet til den som skaper dem, f.eks. ved hjelp av en avgift som reflektere fullt ut de kostnader forurensers utslipp skaper for andre. En kan også ha eksterne nyttevirkninger. Et samlebegrep er derfor eksterne effekter eller eksternaliteter.

Skadefunksjonsmetoden (Damage Function Approach) inneholder fem steg for å komme frem til verdsettingsestimat for miljøeffekter, se figur A1-1. Steg 1 beskriver utslipp som følge av produksjon/rensing. Steg 2 beskriver hvilken påvirkning utslippet har på det ytre miljø. Ved hjelp av en spredningsmodell, beregnes endringer i effekter på miljøet $\mathrm{i}$ steg 3, og ved hjelp av dose-respons funksjoner kartlegger man i steg 4 konsekvenser av endring i påvirkningen på miljøet. I steg 5 foretas det økonomisk verdsetting av miljøeffekter. Dette steget kan gjøres i form av nye verdsettingsstudier eller ved å overføre estimat for tidligere undersøkte, liknende miljøeffekter (såkalt «benefit transfer»). 
Figur A1-1: Skadefunksjonsmetoden

\begin{tabular}{|c|c|c|c|}
\hline & PROSESS - STADIER & & MODELL / DATA \\
\hline \multirow[t]{2}{*}{ Definere produksjons- og renseteknologi } & TEKNOLOGI & & \\
\hline & $\checkmark$ & 4 & UTSUPPSMODELL \\
\hline \multirow[t]{2}{*}{ Kartlegge påvirkning på ytre miljø } & PAVIRKNING / UTSLIPP & & \\
\hline & $t$ & 4 & SPREDNINGSMODELL \\
\hline \multirow{2}{*}{ Regne ut endret effekter på miljø } & $\begin{array}{c}\text { ENDREDE } \\
\text { KONSENTRASJONER }\end{array}$ & & \\
\hline & $\downarrow$ & 4 & $\begin{array}{l}\text { DOSE-RESPONS } \\
\text { FUNKSJONER }\end{array}$ \\
\hline \multirow[t]{2}{*}{ Konsekvenser av effektendringer } & $\begin{array}{l}\text { KONSEKVENSER } \\
\text { FOR MIUø OG HELSE }\end{array}$ & & \\
\hline & 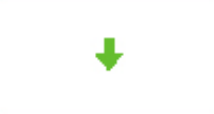 & 4 & $\begin{array}{l}\text { VERDSETIINGS-DATABASE } \\
\text { OG BENEFIT TRANSFER, } \\
\text { ELLER } \\
\text { NY VERDSETIINGSSTUDIE }\end{array}$ \\
\hline $\begin{array}{l}\text { Økonomisk verdsetting av konsekvensene, } \\
\text { regne ut aggregert miljøkostnad }\end{array}$ & KOSTNAD / NYTTE & & \\
\hline
\end{tabular}

Det er viktig at endepunktet for et steg er startpunktet for neste, eller at det finnes en kjent sammenheng mellom dem. Eksempelvis må endringen i konsentrasjon i steg 3 ha sammenheng med effekter for miljø og helse i steg 4 og disse effektene må kunne måles på en måte eller i en enhet som kan verdsettes i steg 5 . For noen typer prosjekter kan man gå direkte fra steg 1 til steg 5, da effekten i stor grad er direkte og vil være gitt av påvirkningen (Navrud, 2002). Dette gjelder for eksempel landskapsestetiske effekter ved kraftinstallasjoner, som for eksempel vindmøller og kraftlinjer.

\section{A1.1.2 Verdsettingsmetoder}

Samfunnsøkonomisk nytte av en miljøforbedring måles som de berørte individers maksimale betalingsvillighet for å få miljøforbedringen, og fortsatt ha samme nytte (eller livskvalitet) som i situasjonen med opprinnelig inntekt og miljøkvalitet.

Denne samfunnsøkonomiske nytteverdien måles som endring i Total Samfunnsøkonomisk Verdi (TSV). TSV kan inndeles i to hovedkomponenter; bruksverdi og ikke-bruksverdi, avhengig av hva som motiverer individenes betalingsvillighet. Bruksverdien er individets maksimale betalingsvillighet (BV) for å bruke godet. Dette kan være konsumerende bruk som ved jakt, eller ikke-konsumerende bruk som ved dyrefotografering eller -observasjoner. Ikke-bruksverdi omfatter opsjonsverdi (med opsjon menes her at en er villig til å betale en sum for å sikre seg muligheten til konsumerende bruk i framtida, og det å vite at en dyrepopulasjon eller et 
økosystem/naturområde bevares for nåværende generasjon (eksistensverdien) og dermed kan overføres til framtidige generasjoner (bevaringsverdien).

Det går et skille mellom metoder basert på individers preferanser, som er i samsvar med økonomisk velferdsteori (inkludert dets anvendte verktøy; nytte-kostnadsanalyser(NKA)) og ekspertvurderinger, vist i tabell A1-1.

Tabell A1-1: Klassifisering av metoder for verdsetting av miljøgoder/fellesgoder

1) Metoder basert på individuelle preferanser

\begin{tabular}{|l|l|l|}
\hline & Indirekte & Direkte \\
\hline $\begin{array}{l}\text { Revealed preferences (RP) } \\
\text { (Avslørte preferanser) }\end{array}$ & $\begin{array}{l}\text { Transportkostnadsmetoden } \\
\text { (TKM) } \\
\text { Hedonic Pricing (HP) (Eien- } \\
\text { domsprismetoden) } \\
\text { Kostnader ved forebyggende } \\
\text { tiltak }\end{array}$ & Simulerte markeder \\
& $\begin{array}{l}\text { Markedspriser (Skyggepriser) } \\
\text { Choice Experiment (CE) } \\
\text { - Conjoint Analysis (CA) } \\
\text { - Contingent Ranking (CR) }\end{array}$ & Contingent Valuation (CV) \\
\hline $\begin{array}{l}\text { Stated preferences (SP) } \\
\text { (Oppgitte preferanser) }\end{array}$ & & \\
\hline
\end{tabular}

2) Metoder basert på beslutningstakeres/ekspertenes preferanser.

\begin{tabular}{|l|l|l|}
\hline & Indirekte & Direkte \\
\hline $\begin{array}{l}\text { Revealed preferences (RP) } \\
\text { (Avslørte preferanser) }\end{array}$ & Implicit costs & \\
\hline $\begin{array}{l}\text { Stated preferences } \\
\text { (SP) } \\
\text { (Oppgitte preferanser) }\end{array}$ & Flermåls Beslutningsanalyse & $\begin{array}{l}\text { Delfi-metoden og andre ekspert- } \\
\text { vurderingsmetoder }\end{array}$ \\
\hline
\end{tabular}

Kilde: Navrud (2002)

For metoder som bygger på individers preferanser skilles det mellom «avslørte preferanser» (RP - Revealed preferences) og «oppgitte preferanser» (SP - Stated preferences). Under avslørte preferanser viser individet sine preferanser for å få/unngå en marginal endring i miljøgodet gjennom deres oppførsel/faktiske handlinger i markeder som har sammenheng med miljøgodet (for eksempel markedet for transporttjenester), eller hvor dette er innbygget (for eksempel eiendomsmarkedet). I metoder som bygger på «oppgitte preferanser» presenteres hypotetiske markeder hvor individet blir bedt om å vurderer alternativer og dermed oppgir sine preferanser for marginale endringer i et miljøgode.

Under indirekte RP-metoder finner vi Transportkostnadsmetoden (TKM), Eiendomsprismetoden (HP - Hedonic Pricing ) og Kostnader ved forebyggende tiltak. TKM forsøker å fastslå bruksverdien for et miljøgode ut i fra kostnader folk har på reise, inngangsbilletter, på-stedet-utgifter og utgifter til utstyr for å utøve en rekreasjonsaktivitet. Deres rekreasjonsverdi måles da som det de er villige til å betale for å utøve aktiviteten utover de kostnader de i dag har ved aktiviteten; dvs. det såkalte kon- 
sumentoverskuddet. Metoden har blitt benyttet til å verdsette bl.a. verdien av fritidsfiske, jakt og friluftsliv (Hanley et. al 1993).

Utgangspunktet for HP-metoden er at bruksverdien av et omliggende miljøgode/onde kan reflekteres i eiendomspriser. Metoden har blitt benyttet til å verdsette støy fra trafikk, luftforurensing, miljøeffekter knyttet til avfallsdeponier og landskapsestetiske effekter av utbygginger.

Kostnader folk har ved tiltak som kan forebygge eller unngå en miljøforverring, kan også tolkes som en minste betalingsvillighet individer har for å unngå miljøforverringen.

Ved direkte RP forsøker man å simulere markeder og markedspriser. Simulerte markeder innebærer at man etablerer et marked for miljøgodet og dermed kan undersøke folks faktiske betalingsvillighet. Eksempler på dette er folkeavstemminger som er benyttet i f.eks. Sveits og delstater i USA for å stemme over offentlige programmer som gir endret tilgang på miljøgoder til en oppgitt pris (Navrud 2001). Disse metodene omfatter også «Replacement costs», som altså er kostnadene ved å erstatte tapte økosystemfunksjoner; for eksempel kostnaden av å bygge et renseanlegg som har samme rensekapasitet som et våtmarksområde.

Markedspriser for leie av jakt- og fiskerettigheter kan også benyttes som et uttrykk for den bruksverdi folk har av disse miljøgodene.

Av indirekte SP metoder er Choice Experiments (CE) en fellesnevner for flere typer metoder. En av disse er Samvalgsanalyser (CA - Conjoint Analysis), som med parvis sammenlikning er den mest brukte. Metoden ber folk foreta gjentatte valg mellom to alternativer med egenskaper med skiftende verdi, hvorav en av egenskapene er pris eller kostnad. I betinget ranking (CR - contingent ranking) blir deltakerne derimot bedt om å rangere alternativer istedenfor å velge mellom dem. I begge tilfeller kan den samfunnsøkonomiske verdien av alternativene og deres egenskaper beregnes ut fra de valg individene gjør (gitt at en egenskap har en monetær måleenhet).

Blant de direkte SP metodene finnes den mest brukte verdsettingsmetoden, Betinget Verdsetting (CV - Contingent Valuation). CV spør folk direkte spørsmål om deres maksimale betalingsvillighet (WTP - willingness-to-pay) eller minimale kompensasjon (WTA - willingness to accept compensation) for å få/unngå en endring i kvaliteten eller mengden av et miljøgode. Metoden ble først benyttet i USA, og gjennom empirisk og teoretisk forskning har CV metoden blitt den mest brukte blant verdsettingsmetoden (Hanley and Spash 1993, Bateman and Willis 1999). Metoden regnes som den mest anvendelige av verdsettingsmetodene da den har potensial til å måle alle deler av TSV, og kan verdsette fremtidige miljøendringer (i motsetning til for eksempel TKM som kun måler bruksverdien, og kun av dagens bruk av godet).

For metoder basert på beslutningstageres/eksperters preferanser, blir utvalgte gruppers preferanser kartlagt. Under Flermåls beslutningsanalyser/multikriteria analyser (FMBA) blir et utvalg av interessegrupperepre- 
sentanter eller beslutningstakere bedt om å oppgi sine preferanser for ulike alternativer som er beskrevet ved ulike egenskaper som for eksempel miljøeffekt, pris/kostnad osv.). Verdien på egenskapene endres og beslutningstaker blir bedt om å velge på nytt. Det er utviklet dataprogrammer for å presentere valgene og beregne nyttefunksjoner basert på de valg deltakerne gjør (Navrud, 2001). Ved delfi-teknikker, blir deltakerne spurt direkte om deres vekter/verdier. Deltagerne er her eksperter som først blir spurt om sin verdsetting og får deretter mulighet til å korrigere dette når de har hørt hva alle de andre har oppgitt.

\section{A1.1.3 Overføringsmetoder (Benefit transfer)}

Dersom det forligger en eller flere verdsettingsstudier for et endepunkt av en dose-responsfunksjon i skadefunksjonstilnærmingen (se steg 5 i figur A1-1), er det spørsmål om man kan overføre verdianslagene fra stedet studien ble foretatt («studiestedet») til det nye stedet man ønsker verdier for («beslutningsstedet»). En slik overføring kalles «benefit transfer» (nytte-overføring). Metoden gjelder imidlertid både for overføring av nytte (benefit) og skade (damage), og burde heller generelt benevnes «Value Transfer» (Navrud 2004).

Fordelen med en slik overføring av verdianslag er at dette oftest er billigere enn å utføre nye studier. En annen og ofte like viktig faktor, er at gjennomføring av nye studier er tidkrevende, og overføring av verdsettingsestimat fra eksisterende studier kan dermed være en langt raskere metode.

Svakheten med benefit transfer, er at usikkerheten i verdianslagene $ø$ øer. Dette kan skyldes at selv om tidligere undersøkelser har verdsatt samme type miljøgode, kan det være flere viktige forskjeller. Dette kan for eksempel være ulike karakteristika ved miljøgodet, ulik endringer av miljøgodets kvalitet/mengde, ulik tilgjenglighet av substituttet, og ulik beslutningssammenheng for verdsettingen. I tillegg kan det være forskjeller for eksempel i inntekt, utdanning, preferanser og holdninger hos involverte som vil kunne medføre forskjellig verdsetting av samme miljøendring (Navrud, 2001). Disse usikkerhetene kommer i tillegg til usikkerhetene som allerede ligger i de originale verdsettingsmetodene, og de andre stegene i skadefunksjonsmetoden, vist i figur A1-1. Økningen av usikkerhet i estimatene ved nytteoverføringen må vurderes opp mot nytte ved redusert tid og kostnad i forhold til en original verdsettingsstudie, samt en vurdering av akseptabelt usikkerhetsnivå (Navrud 2004).

Det finnes tre hovedtyper av overføringsteknikker (Benefit Transfer teknikker) (Navrud, 2001, 2002 og 2004), nevnt under.

\section{A1.1.3.1 Enhetsverdioverføring}

Enhetsverdioverføring, dvs. overføring av estimater for gjennomsnittlig betalingsvillighet for et bestemt miljøgode fra det opprinnelige studieste- 
det til stedet der ny analyse ønskes utført, er den enkleste formen av overføringsteknikker. Denne overføringen kan foregå med eller uten korrigeringer av forskjeller mellom de to stedene. Korrigeringer kan være på bakgrunn av prisstigning, inntektsnivå eller ekspertanslag av ulikheter mellom studiested og beslutningssted. Det tilstrebes å finne studier som i størst mulig grad likner beslutningsstedet, men overføringen kan også baseres på anslag av flere originale verdsettingsstudier.

\section{A1.1.3.2 Overføring av betalingsvillighetsfunksjon}

Dette innebærer at betalingsvillighetsfunksjonen, det vil si estimert betalingsvillighet for endringer i miljøgodet som en funksjon av forskjellige forklaringsvariabler (så som respondentenes inntekt, utdanning, bruk og kjennskap til miljøgodet etc) overføres. Estimering av betalingsvillighet på beslutningsstedet skjer da ved å bruke de samme koeffisientene og middelverdiene fra beslutningsstedet settes inn for forklaringsvariablene. Dette betinger at miljøendringene og forklaringsvariablene er sammenlignbare og at respondentenes preferanser er tilsvarende mellom studiested og beslutningssted. Det tilstrebes å finne studiested som i størst mulig grad likner beslutningsstedet, og det må finnes data for forklaringsvariablene tilgjengelig på beslutningsstedet.

\section{A1.1.3.3. Meta-analyse}

Meta-analyse er statistisk regresjonsanalyse av flere tidligere verdsettingsstudier for et bestemt miljøgode, for å se hvordan betalingsvilligheten for miljøgodet varierer. med ulike karakteristika ved godet, den undersøkte befolkningen og aspekter ved verdsettingsmetoden som er anvendt. Da hver studie blir benyttet som en observasjon, er det problematisk å gjennomføre meta-analyser for miljøgoder hvor det er utført få tidligere studier, da man vil få problemer med få observasjoner (og få frihetsgrader) i regresjonene. Det kan brukes flere estimat fra samme studien dersom det for eksempel er brukt ulike verdsettingsspørsmål i originalstudien, men man må da ta hensyn til korrelasjon i observasjonene.

\section{A1.2 Retningslinjer for benefit transfer}

Det finnes få detaljerte retningslinjer for overføringer av verdier fra tidligere verdsettingsstudier. Dette kapittelet baserer seg på rapporten «Practical Tools for Benefit Transfer in Denmark - Guidelines and an Example» (Navrud, 2006).

I USA finnes det enkelte rapporter som dekker hovedelementene for hvordan man skal utføre benefit transfer, spesielt gjelder dette Desvouges et al (1998), som gir føringer for hvordan benefit transfer kan utføres for helseeffekter av luftforurensing knyttet til produksjon av elektrisitet. For bruk på miljøgoder generelt, vil vi foreslå følgende åtte steg: 
1. Identifiser miljøendringen som ønskes verdsatt på beslutningsstedet1

2. Identifisert berørt populasjon på beslutningsstedet

3. Utfør en gjennomgang av litteratur for å identifisere relevante utførte primærstudier

4. Vurder relevans og kvalitet på verdier fra tidligere studier i forhold til benefit transfer muligheter

5. Velg ut og sammenfatt tilgjengelig data fra tidligere studie(r)

6. Overfør verdier fra studie- til beslutningssted

7. Kalkuler endringens totale nytte og kostnader

8. Vurder usikkerhet i overføringene og akseptabel overføringsfeil

\section{A1.2.1 Steg 1 - Identifiser miljøendringen som ønskes verdsatt på beslutningsstedet}

1. Type miljøgode

Den totale samfunnsøkonomiske verdien (se foregående kapittel) av et miljøgode kan grovt sett deles inn i tre grupper:

a. Direkte bruksverdier (for eksempel rekreasjonsaktiviteter som svømming, fotturer, fiske og jakt)

b. Indirekte bruksverdier (for eksempel opprettholdelse av biodiversitet, klimaeffekter, vannressurser (vannkvalitet og tilgang på vann), kontroll av jorderosjon og estetiske landskapsverdier)

c. Ikke-bruksverdier (eksistens- og bevaringsverdier inkludert historiske/kulturelle verdier og truede dyrearter)

2. Beskrive (forventet) miljøforandring

a. Utgangspunkt

b. Omfang og retning på forandring (nytte vs. kostnad samt bevaring 2 vs. restaurering)

\section{A1.2.2 Steg 2 - Identifisere den berørte populasjonen på} beslutningssteget

Desvousges et al. (1998) bruker dette som siste steg i deres retningslinjer for gjennomføring av benefit transfer. Det er imidlertid viktig å identifise-

\footnotetext{
${ }^{1}$ Med «beslutningssted» menes det geografiske stedet hvor det ønskes å gjennomføre en ny verdsetting av en miljøendring. Med «studiested» menes det geografiske området hvor en verdsetting av et miljøgode allerede er gjennomført.

${ }^{2}$ Det bør skilles mellom bevaring (som bevarer original/uberørt miljø) og restaurering. Det har vist seg at befolkningen setter en høyere verdi på å beholde et uberørt miljø (dvs. bevare) i forhold til restaurering på et senere tidspunkt.
} 
re den berørte populasjonen på beslutningsstedet allerede før vi gjennomgår litteratur og vurderer relevansen av de utvalgte studier. Verdiene som overføres fra tidligere studier bør stamme fra et utvalg med relativt like demografiske egenskaper og verdier som ved beslutningsstedet.

Dersom vi kun ønsker å komme frem til verdier av en friluftsaktivitet, vil for eksempel den berørte populasjonen være de som benytter dette området til rekreasjon. Dersom vi ønsker å verdsette både bruks- og ikkebruksverdier, og beslutningsstedet kun har lokal verdi bør utvalget komme fra fra den aktuelle kommune (eller området som benytter godet). Dersom det kun er noen få substitutter regionalt bør utvalget komme fra flere kommuner eller eventuelt fra hele fylket. Dersom miljøgodet er av nasjonalt viktig karakter, for eksempel en nasjonalpark eller en unik nøkkelbiotop, bør utvalget representere hele landet.

For bruksverdier bør antall personer som bruker området til rekreasjonsformål estimeres (før og etter miljøforandringen), mens for ikkebruksverdier (eller bruks- og ikke-bruksverdier sammenlagt) bør antall berørte husstander bli aggregert på det relevante geografiske nivået (kommune/fylke/regionalt/nasjonalt nivå).

\section{A1.2.3 Steg 3 - Utfør en litteraturgjennomgang for å identifisere relevante primcere verdsettingsstudier}

Neste steg er å gjennomføre et søk i databasen EVRI, www.evri.ca (som nå inneholder alle nordiske studier som er spesifisert i vedlagt regneark over verdsettingsstudier) for å identifisere liknende studier fra samme land eller naboland (eller andre land som er relevante å sammenlikne seg med). Denne anbefalingen er basert på benefit transfer validitetstester, som viser at overføringer mellom land og områder som har liknende demografiske kvaliteter generelt sett har mindre overføringsfeil. Av samme årsak bør man velge de nyeste studiene. Uansatt bør man være oppmerksom på at validitetstestene ikke innebærer at dette vil være tilfellet for alle overføringer.

Dersom det ikke eksisterer noen, eller kun et fåtall primærstudier av den aktuelle miljøendringen i Norden, bør hele EVRI-databasen (og eventuelt andre oversikter) gjennomgås med henblikk på relevante studier. Meta-analyser (inkludert nordamerikanske studier) kan også vurderes, gitt at man tar hensyn til de begrensninger overføring av verdier fra metaanalyser med et bredt omfang har (for eksempel for stor variasjon i definisjon av miljøgodet i studier inkludert i meta-analysen). Noen metaanalyser finnens også i EVRI-databasen. Lindhjem (2006) har laget et regneark med gjennomgang av alle studier av ikke-tømmerverdier som er gjennomført i Norge, Sverige og Finland, og bruker dette til å gjennomføre en meta-analyse. To viktige konklusjoner kan dras fra denne studien; i) Betalingsvillighet synes ikke å være sensitiv til størrelsen på skogsområder, noe som kan skape tvil om forenklede mål for betalingsvillighet pr. 
arealenhet for komplekse miljøgoder ii) betalingsvillighet synes å være høyere dersom det er personene og ikke husholdninger som inngår i studien. Nordamerikanske meta-analyser kan også bli gjennomgått (siden de fleste studier av denne typen har blitt utført der); for eksempel Rosenberger \& Loomis (2000) og Shrestha \& Loomis (2001).

Databaser med verdsettingsstudier inneholder sjelden all informasjon man trenger om studien for å gjennomgå egenskaper ved studiestedet, og selve studien bør dermed også gjennomgås.

\section{A1.2.4 Steg 4 - Gjennomgå relevansen og kvaliteten $i$} verdsettingsestimatene fra studien for mulig benefit transfer

I denne delen bør kvaliteten på den aktuelle verdsettingsstudien gjennomgås i forhold til vitenskaplige kriterier og omfang av informasjon. Desvousges et al. (1998) bruker følgende kriterier for å bedømme om en studie er aktuelt for benefit transfer:

1. Vitenskaplig nivå - benefit transfer estimatene er bare så gode som metodikken og forutsetningene i originalstudien tilsier

a. Vitenskaplig forsvarlig datainnsamling (for studier basert på oppgitte preferanser menes med dette personlige intervju og/eller post/internett undersøkelser med høy responsrate (> $50 \%$ ), og utarbeidelse av spørreskjema basert på fokusgrupper og pretester av skjemaets ordlyd og scenarier)

b. Vitenskaplig forsvarlig metodikk (for eksempel personlig intervju med tilstrekkelig utvalgsstørrelse (se for eksempel Bateman et al (2002) for retningslinjer ved studier av oppgitte preferanser og Soutukorva og Söderqvist (2005) for retningslinjer for vurdering av kvalitet av studier innen både avslørte og oppgitte preferanser)

c. Konsistens med vitenskaplig (økonomisk) teori (for eksempel at det eksisterer en sammenheng mellom sluttpunkt i dose-respons funksjoner og verdsettingsestimatet, gjennomførte statistiske analyser og at verdsettingsfunksjonen inneholder variabler som man bør forvente ut i fra økonomisk teori (for eksempel inntekt, utdanning, alder etc)

2. Relevans - Originalstudien bør samsvare og være passende for å kunne brukes i «ny» kontekst

a. Omfanget av miljøendringen bør samsvare

b. Utgangspunktet for miljøkvaliteten bør samsvare

c. Berørt økosystem og miljøgode bør samsvare

d. Det berørte området bør samsvare, når dette er relevant for studien (for eksempel ved verdsetting av rekreasjonsverdier) 
e. Varighet og sammenheng miljøendringen skjer under bør samsvare

f. Sosioøkonomiske karakteristika for den berørte populasjonen bør samsvare

g. Eiendomsrett, kultur og institusjonell setting bør samsvare

3. Detaljgrad - Originalstudien bør inneholde et detaljert datasett med tilhørende informasjon

a. Kartlegg den originale verdsettingsfunksjonen, inkludert full informasjon og definisjoner av underliggende variabler og estimat, og snittverdier for disse

b. Forklaring på hvordan eventuelle substitutter (eller komplementære goder) har blitt håndtert

c. Data for svarprosent, andel nullsvar og andel positive svar

d. Standardavvik og andre statistiske mål på resultatenes spredning

Alle disse tre kriteriene, med underliggende komponenter er like viktige for å vurdere relevans og kvalitet i studien.

\section{A1.2.5 Steg 5 - Velg ut og oppsummer tilgjengelig data fra studiestedet}

Flere mulige fremgangsmåter kan bli brukt for dette og resultatene bør presentere et sett av verdier.

Tidligere studier gjennomgås for å komme frem til laveste og høyeste estimat, som kan definere øvre og nedre begrensing for overførte verdier. Undersøk gjennomsnittsverdier, standardavvik og overføringsfeil (dersom ikke dette finnes, benyttes intervall på \pm 25 - 40 \% basert på tidligere testing av validiteten for benefit transfer (Navrud, 2004)). Undersøk om det finnes relevante meta-analyser som har et omfang som er spesifikt nok til å gi relevant informasjon for benefit transfer. Meta-analyser kan være svært brede i sine anslag, da de ofte inkludere ulike studier med varierende metodikk og av ulike miljøgoder.

Vurder verdiene fremkommet fra meta-analyse i lys av om parameterne i meta-funksjonen har fremkommet i henhold til beste metodikk og en kontekst som samsvarer med beslutningsstedet. Metodiske variabler i meta-analysen (ved CV studier) som kommer fra beste metodikk for utførelse av en betalingsvillighetsundersøkelse (fortrinnsvis personlige intervju eller postale undersøkelser med høy responsrate) bør følge NOAApanelets retningslinjer for CV - undersøkelser (Arrow et al. (1993) - år for studien kan dermed brukes som et første anslag på kvalitet i metaanalyser), så lik som mulig i forhold til omfang og retning på miljøforandring, substitutter, karakteristika for utvalg og troverdig og fornuftig betalingsmiddel (ikke frivillig bidrag eller betalingsmiddel som kan skape en stor andel protestsvar). 


\section{A1.2.6 Steg 6 - Overfør verdier fra studie- til beslutningssted}

1. Fastslå hvilke verdier som skal overføres. Anbefalt verdier for overføring av bruks- og ikke-bruksverdier er:

a. Bruksverdier

For rekreasjon: Konsumentoverskudd pr. aktivitetsdag ${ }^{3}$

For økosystemer: Betalingsvillighet / husholdning / år

For rekreasjon kan konsumentoverskudd for pr år (eller pr besøk) pr besøkende også benyttes, men da bør gjennomsnittlig antall aktivitetsdager pr. år (eller per besøk) være tilsvarende på studieog beslutningssted.

For økosystemer kan det alternativt benyttes for eksempel en pr. enhets kostnad av karbon (tonn) (med sensitivitetsanalyse) for utslipp, dersom denne kostnaden er basert på rensekostnader (som igjen bygger på kvotepriser for $\mathrm{CO}_{2}$ ) fra modellerte skader

b. Ikke-bruksverdier

Bruk av total betalingsvillighet pr hektar økosystem eller landskapstype forutsetter både at størrelsen på berørt populasjon og verdien pr hektar er konstant. Empiriske studier viser imidlertid at betalingsvilligheten faktisk ikke øker proporsjonalt med antall hektar av økosystemet eller landskapstypen (for ikketømmerverdier; se Lindhjem 2006). Studier innen oppgitte preferanser har vist at betalingsvillighet pr. enhet varierer mye, og det bør dermed vises stor forsiktighet med å konvertere oppgitt gjennomsnittlig betalingsvillighet pr husstand til kontinuerlige variabler som betalingsvillighet pr km eller pr ha pr husholdning. En slik verdi vil likevel være bedre enn en total betalingsvillighet $\mathrm{pr}$ km eller hektar, fordi man i det siste tilfellet også må forutsette en tilsvarende berørt populasjon på studie- og beslutningsstedet.

2. Fastslå metode for å korrigere for ulikheter mellom studie- og beslutningssted

Dersom beslutningsstedet har liknende egenskaper med studiestedet, kan enhetsoverføring benyttes med hell. Dersom det finne flere passende studier å overføre verdier fra, bør samtlige vurderes og verdier beregnes som et intervall.

Dersom det benyttes enhetsoverføring mellom ulike land, med ulik valuta, kan inntekt og prisnivå mellom land korrigeres for ved å bruke kjøpekraftparitetsjusterte valutakurser, se for eksempel

\footnotetext{
${ }^{3}$ En aktivitetsdag er definert som ett individ som bedriver en spesifisert rekreasjonsaktivitet for en kortere eller lengre periode i løpet av én dag, for eksempel en fiskedag eller en jaktdag.
} 
http://www.oecd.org/dataoecd/61/56/1876133.xls. Også innen ett land kan det være aktuelt å justere for ulikheter i inntektsnivå og inntektselastisitet i forhold til betalingsvillighet for undersøkt miljøgode.

Overføring av betalingsvillighetsfunksjon kan benyttes dersom denne har tilstrekkelig forklaringsgrad ${ }^{4}$ og inneholder forklaringsvariabler som det også er mulig å finne informasjon om på beslutningsstedet. Imidlertid vil det svært ofte være slik at funksjonen inneholder variabler som gjør at nye undersøkelser må gjennomføres på beslutningsstedet for å skaffe informasjon om disse (for eksempel variabler som sier noe om utvalgets holdninger (politiske og samfunnsmessige)). Dersom modellen kun er basert på variabler som det er mulig å fremskaffe informasjon om på beslutningsstedet (ofte inntekt, alder, utdanning etc som er tilgjengelig i offentlige databaser) vil man ofte oppleve at modellen har lav forklaringsgrad. Generelt oppleves det ofte at betalingsvillighetsundermodeller basert på oppgitte preferanser, har lavere forklaringsgrad enn modeller basert på reisekostnadseller eiendomsprismetoden ${ }^{5}$.

Dersom det eksisterer relevante meta-analyser av miljøendringen (se forrige steg) kan også estimater med utgangspunkt i disse bli benyttet for å sammenlikne ulike benefit transfer metoder. Det kan gjennomføres følsomhetsanalyser for å belyse hvor mye estimatene kan variere og øvre og nedre verdier kan benyttes som intervall for den overførte verdsettingen av miljøforandringen.

Som en oppsummering kan enhetsoverføring sies å være den enkleste og mest transparente måten å overføre verdier mellom studie- og beslutningssted. Metoden har likevel vist seg å være like pålitelig som de mer kompliserte metodene som overføring av betalingsvillighetsfunksjon og meta-analyser. Dette skyldes hovedsakelig den lave forklaringsgraden som betalingsvillighetsfunksjoner fra verdsettingsundersøkelser med oppgitte preferanser har, samt det faktum at valg av metodikk, mer enn karakteristika ved beslutningsstedet og berørt populasjon, har den største forklaringsgraden i meta-analyser. Generelt sett bør et intervall på $\pm 25-40 \%$ benyttes tilknyttet et betalingsvillighetsestimat, dersom studie- og beslutningsstedet er svært like (se Navrud, 2004). Dersom det er store ulikheter mellom studieog beslutningssted, bør det benyttes et intervall på $\pm 100 \%$.

3. Fastslå metode for midlertidig overføringer av verdsettingsestimater

\footnotetext{
${ }^{4}$ Som en tommelfingerregel bør dette være en justert $R^{2}$-verdi høyere enn 0,5 , noe som innebærer at mer enn $50 \%$ av variasjonen i betalingsvillighetsestimatet er forklart ved endring $\mathrm{i}$ forklaringsvariablene.

${ }^{5}$ Dette innebærer imidlertid ikke at vi bør fokusere på studier basert på avslørte preferanser når nye studier planlegges, da kun metoder basert på oppgitte preferanser har kapasitet til å måle ikke-bruksverdier for miljøgoder.
} 
Verdsettingsestimatet bør justeres for tid fra dataene ble innsamlet til dagens prisnivå, ved bruk av konsumprisindekser (KPI) hentet fra området hvor beslutningsstedet ligger. Dersom studiestedet ligger i et annet land enn beslutningsstedet, må det først konverteres til lokal valuta i det året dataene ble innsamlet, ved å bruke PPP - (Purchasing Power Parity - kjøpekraftparitet) justerte valutakurser fra dette året. Deretter benyttes KPI ved beslutningsstedet (oftest landet dette ligger i for å oppdatere verdiene til det tidspunktet da ny verdsetting ønskes gjennomført).

Da miljøgoder ikke inkluderes i KPI, kan det imidlertid være verdt å merke seg at miljøendringen kan ha steget mer eller mindre enn denne indeksen. Det eksisterer imidlertid pr i dag ingen bedre metode for å justere for endringer i preferanser for miljøgoder over tid.

\section{A1.2.7 Steg 7 - Kalkulere total nytte eller kostnader}

For overføring av ikke-bruksverdier blir gjennomsnittlig betalingsvillighet/husstand/år multiplisert med totalt antall berørte husstander, for å komme frem til årlige nytte eller kostnader. Dersom betalingsvilligheten for studien er anslått som årlige verdier i et gitt tidsintervall, for eksempel 5 eller 10 år, skal den totale nytte eller kostnad beregnes som en nåverdi av den samme perioden. Dersom verdien derimot er oppgitt som et engangsbeløp, skal dette betraktes som en nåverdi av miljøforandringen i undersøkelsen.

Den generelle formelen for å kalkulere en nåverdi av nytte av et miljøgode, $\mathrm{NV(B)}$ kan uttrykkes som:

$$
\begin{aligned}
& T \\
& N V(B)=\Sigma B_{t} /(1+r)^{t} \\
& \mathrm{t}=0
\end{aligned}
$$

hvor $B_{t}$ er den total nytte av miljøgodet i år t, $T$ er tidshorisonten (for den oppgitte betalingsvilligheten) og $r$ er samfunnets diskonteringsrate. Nytte og diskonteringsrate er oppgitt i realverdier, dvs. at 2006-euro og diskonteringsrate; oppgitt som realavkasting (dvs. justert for inflasjon, og ikke som en nominell rente).

Dersom det ikke er oppgitt en tidshorisont i betalingsvillighetsundersøkelsen bør det antas at dette er en årlig innbetaling over en uendelig tidshorisont, dvs. at $\mathrm{t} \rightarrow \infty$. I dette tilfellet vil den årlige nytten $\mathrm{B}_{\mathrm{t}}$ være den samme hvert år og ovenstående funksjon kan forenkles til:

$P V(B)=B_{t} / r$ 
Årlig nytte $\mathrm{B}_{\mathrm{t}}$ tilsvarer aggregert betalingsvillighet for den berørte populasjonen $\left(\mathrm{WTP}_{\mathrm{tot}}\right)$ og kan beregnes som:

$$
\text { WTP }_{\text {tot }}=\mathrm{n} \times \mathrm{WTP}_{\mathrm{i}}
$$

Hvor $\mathrm{n}=$ antall berørte husstander og $\mathrm{WTP}_{\mathrm{i}}=$ gjennomsnittlig betalingsvillighet for husstand $i$. Siden betalingsvillighet pr husstand varierer mellom ulike deler av den berørte populasjonen (for eksempel i forhold til avstand mellom studie- og beslutningssted, i forhold til bruks og ikkebruks konsumenter etc.) bør estimatet baseres på den samme type berørt populasjon som ved beslutningsstedet. Dersom dette ikke er mulig, bør reduksjon i betalingsvillighet som følge av avstand fra miljøgodet (såkalt «distance decay», for eksempel prosentvis reduksjon i betalingsvillighet pr. km økt avstand fra miljøgodet) anslås, basert på empirisk erfaring fra studiestedet (dersom det eksisterer og tilsier dette).

Dersom det skal beregnes bruksverdier for rekreasjon, bør husstander erstattes med individer i ovennevnte likning, og konsumentoverskudd pr aktivitetsdag multipliseres med økt eller redusert antall dager aktivitet for å beregne prosjektets totale verdi. For verdier utover rekreasjon, benyttes oftest verdi pr husstand, og samme metoder som for ikke-bruksverdier kan benyttes.

Når nytte eller kostnader av et miljøgode skal aggregeres, må det også vurderes om disse godene er uavhengige (som innebærer at de summeres direkte), eller om de bør betraktes som substitutter eller komplementære goder. I det første tilfellet vil aggregert nytte eller kostnad bli overestimert, mens de i det siste tilfellet vil kunne underestimeres.

\section{A1.2.8 Steg 8 - Usikkerhet og akseptabel overføringsfeil}

Gjennomførte validitetstester for benefit transfer (Navrud, 2004) har vist at overførte økonomiske estimater bør presenteres innen et intervall på \pm $40 \%$. Dersom studie- og beslutningssted er svært like, eller dersom primærstudien ble laget med tanke på overføringer til områder som tilsvarer beslutningsstedet, kan det imidlertid benyttes feilmarginer på $\pm 25 \%$. Dersom det er store forskjeller mellom studie- og beslutningssted, kan det fremdeles benyttes enhetsoverføring, men muligheter for over- eller underestimering i overføringer i verdier bør bli oppsummert og presenteres med innen for et intervall på $\pm 100 \%$ (som baseres på observert variasjon i verdsettingsestimater i validitetstester (Navrud, 2004)).

Dersom det skal gjennomføres en nyttekostnadsanalyse av et nytt prosjekt eller en politikk, skal nåverdien av estimert kostnad sammenliknes med nåverdi av tilsvarende nytte. Effekten av en feilmargin i overføringen på 25-40 \% bør kalkuleres for å vurdere om dette redusere nåverdien av nytten (øker kostnadene) til et kritisk nivå, som for eksempel kan medføre at den totale nåverdien endres fra positiv til negativ. Hvis dette er tilfellet vil evt. overføringsfeil i estimatet være så store at de vil kunne 
forandre konklusjonen i nyttekostnadsanalysen, og presisjonsnivået i overføringen bør forsøkes å forbedres. Dette kan gjøres for eksempel ved å gjennomføre en fullstendig verdsettingsundersøkelse eller ved å korrigere overførte verdier ved å gjennomføre en små-skala verdsettingsundersøkelse (tilsvarende en pilottest).

Dersom det er behov for å anslå verdier for et miljøgode som grunnlag for å foreta en beslutning, bør det gjennomføres en nyttekostnadsanalyse av verdien av en slik undersøkelse, for å kartlegge om kostnadene ved å gjennomføre dette er lavere enn nytten i form av mindre sannsynlighet for å ta en feilaktig beslutning. Disse anbefalingene kan brukes som et anslag på om presisjonsnivået $\mathrm{i}$ et verdsettingsestimat av en miljøforandring basert på benefit transfer metoder er tilfredsstillende.

\section{Referanser}

Arrow, K.J., R. Solow, E. Leamer, P. Portney, R. Radner and H. Schuman 1993: Report of the NOAA Panel on Contingent Valuation. Federal Register, 58, 4601-4614 (January 15, 1993).

Bateman, I and K. G, Willis (eds). 1999: Valuing Environmental Preferences. Theory and Practice of the Contingent Valuation Method in the Us, EU and Devbveloping Countries. Oxford University Press.. Oxford, New York.

Bateman, Ian J. Richard T. Carson, Brett Day, Michael Hanemann, Nick Hanley, Tannis Hett, Michael JonesLee, Graham Loomes, Susana Mourato, Ece Özdemiroglu, David Pearce, Robert Sugden and John Swanson 2002: Economic Valuation With Stated Preference Techniques. A Manual. Edward Elgar Publishing, Cheltenham, UK and Northampton, MA, USA.

Bateman, I.J. and A.P Jones AP 2003: Contrasting conventional with multilevel modelling approaches to metaanalysis: Expectation consistency in UK woodland recreation values. Land Economics 79(2): 235-258.

Desvousges, W.H, F. R. Johnson and H.S. Banzhaf 1998: Environmental Policy Analysis with Limited Information.Principles and Applications of the Transfer Method. New Horizons in Environmental Economics. Edward
Elgar, Cheltenham, UK and Northampton, MA, USA.

Hanley, Nick and Spash, Clive L. 1993: Cost-Benefit Analysis and the Environment.

Lindhjem, H. 2006: Non-Timber Benefits from Fennoscandian Forests: A Meta-Analysis. Forthcoming in Journal of Forest Economics January 2007.

Navrud, S. 2001. Samfunnsøkonomisk nytteverdi av villlaksressursene i nasjonale laksevassdrag - Oppfølgingsstudie, Rapport til Direktoratet for Naturforvaltning.

Navrud, S. 2002 Miljøkostnader og nettinvesteringer, Rapport til NVE.

Navrud, S. 2004: Value transfer and environmental policy. Chapter 5 (pp. 189-217) in Tietenberg, T. and H. Folmer (eds.) 2004: The International Yearbook of Environmental and Resource Economics 2004/2005. A survey of Current Issues. Edward Elgar Publishing, Cheltenham, UK and Northampton, MA, USA.

Navrud, S. 2006. Practical Tools for Benefit Transfer in Denmark - Guidelines and an Example. E-CO Tech rapport på oppdrag fra Miljøstyrelsen Danmark.

Rosenberger, Randall S. and Loomis, John B. 2001. Benefit transfer of outdoor recreation use values: A technical document supporting the Forest Service Strategic Plan (2000 revi- 
sion). Gen. Tech. Rep. RMRS-GTR72. Fort Collins, CO: U.S. Department of Agriculture, Forest Service, Rocky Mountain Research Station. http://www.fs.fed.us/rm/pubs/rmrs_gt r72.pdf

Shrestha, R. K. and J. B. Loomis 2001:

Testing a meta-analysis model for benefit transfer in international out- door recreation. Ecological Economics 39(1): 67-83.

Soutukorva, Å. og T. Söderqvist 2005: Kvalitetskriterier för ekonomiska miljövärderingsstidier. Naturvårdsverket, Stockholm. ISBN 91-620-1247-9.

Also available in English at:

http://www.naturvardsverket.se/bokha ndeln/pdf/620-1252-5.pdf 


\section{Appendix 2}

\section{Referenser till studierna i NEVD}

Aae. R. The Recreational Value of Sports Fishing for Salmon in Drammenselva - Rekreasjonsverdien av fritidsfisk etter laks i Drammenselva. Norwegian University of Life Sciences (UMB). June 1, 1995

Aakerlund, N.F. Contingent Ranking Study of Danish Preferences of Forest Characteristics. The Royal Veterinary and Agricultural University (KVL), and AFK. July 1, 2000

Aakkula, J. Economic Value of ProEnvironmental Farming - A Critical and Decision-Making Oriented Application of the Contingent Valuation Method. Dissertation, University of Helsinki. Publications 92, Agricultural Economics Research Institute, Finland. September 1, 1999

Åkerman, J, F.R. Johnson, and L. Bergman. Paying for Safety: Voluntary Reduction of Residential Radon Risks. Land Economics 67, no. 4, 435-446. November 1, 1991

Alberini, A. Robustness of VSL Values from Contingent Valuation Surveys. NOTA DI LIVORO 135.2004. November 1, 2004

Andersson, Å. Estimating the Potential Ecological Retention/Elimination Service Performed by Natural Wetlands in the Baltic Sea Drainage Basin. Master thesis 1994:9, Department of Systems Ecology, Stockholm University. December 1, 1994

Anthon S. and B.J. Thorsen. Valuing afforestation, a hedonic approach Værdisætning af statslig skovrejsning. En husprisanalyse. Report for the Forest and Nature Agency, Ministry of the Environment, Denmark. July 1, 2002

Appelblad, H. The Spawning Salmon as a Resource by Recreational Use. The case of the wild Baltic salmon and conditions for angling in north Swedish rivers. Doctoral thesis, GERUM 2001:3, Department of Social and
Economic. Geography, Umeå University. January 1, 2001

Atkins, J.P. and D. Burdon. An Initial Economic Evaluation of Water Quality Improvements in the Randers Fjord, Denmark. Marine Pollution Bulletin, article in press. January 1, 2005

Axelsen, L.K. Environmental Accounting for Wind Energy - Miljøregnskap for vindkraft

Norwegian University of Life Sciences (UMB). August 1, 2003

Barker, T., and R. Knut. Ancillary Benefits of GHG Mitigation in Europe: SO2, NOx, PM10 Reductions from Policies to Meet Kyoto Targets Using the E3ME Model and Externe Valuations. Commission of European Communities, Directorate-General XII for Science, Research and Development. March 1, 2000

Bergland, O. Valuing Aesthetical Values of Weirs in Watercourses with Hydroelectric Plants - Verdsetjing av estetiske verdiar i tilknytning til tersklar i regulerte vassdrag. Norwegian Water Resources and Energy Directorate (NVE). May 1, 1998

Bergland, O. Estimating Oilspill Damages: The Case of Blücher. Det Norske Veritas Research AS. December 1, 1994

Bjorner, T.B. Comparing the Value of Quiet from Contingent Valuation and Hedonic Pricing Methods. AFK, Institute of Local Government Studies Denmark. December 1, 2003

Bjorner, T.B. Combining Socioacoustic and Contingent Valuation Surveys to Value Noise Reduction. Transportation Research Part D 9, 341-356. January 1, 2004

Bjorner, T.B. and C.S. Russell, A. Dubgaard, C. Damgaard and L.M. Anderson. Public and Private Preference for Environmental Quality in 
Denmark. SOM publikation nr. 39, AKF Forlaget, 2000. January 1, 2000 Bjørkeslett, H.K. and I.M. Lilleby. What is a Clean Fjord Worth? Social Benefit of Measures in Polluted Sediments in the Grenlandsfjords. Norwegian University of Life Sciences (UMB). May 1, 2006

Bjørner T.B, C.C. Russel, A. Dubgaard,C. Damgaard and L.M Andersen. Public and Private Preferences for Environmental Quality in Denmark. AKF forlaget. October 1, 2000 Bjørner, T.B, J. Hauch and S. Jespersen. Biodiversity, Health and Uncertainty - a Contingent Ranking Study. Secretariat of the Danish Economic Council. January 1, 2004

Bjørnsgard, B. Willingness to Pay for the Pilgrim Way to Nidaros Cathedral - Betalingsvillighetsundersøkelse av pilegrimsleden til Nidaros. Norwegian University of Life Sciences (UMB). May 1, 2004

Boiesen J., J.B. Jacobsen, B.J Thorsen, N. Strange and A. Dubgaard. Valuation of Danish moorland - Værdisætning af de danske lyngheder"'" .Arbejdsrapport, KVL, Frederiksberg. September 1, 2005

Bostedt, G. and L. Mattsson. A Note on Benefits and Costs of Adjusting Forestry to Meet Recreational Demands. Journal of Forest Economics, no. 12, 75-81. January 1, 2006

Bostedt, G. and L. Mattsson. The Value of Forests for Tourism in Sweden. Annals of Tourism Research 22, no.3, pp. 671-680. January 1, 1995

Bothe, D. Environmental Costs due to the Kárahnjúkar Hydro Power Project on Iceland

University of Cologne. June 1, 2003

Brander, L.M.; R.J.G.M. Florax; and J.E. Vermaat. The Empirics of Wetland Valuation: A Comprehensive Summary and a Meta-Analysis of the Literature. European Association of Environmental and Resource Economics 13th Annual Conference, Budapest Hungary, June 25th to 28th 2004. June 1, 2004

Brastad, B. and T. Neset. A Socioeconomic Analysis of the Protection Plan for Setesdal Vestehei/Ryfylkeheiane - En samfunnsøkonomisk analyse av verneplan for Setesdal Vestehei/Ryfylkeheiane.
Norwegian University of Life Sciences (UMB). June 1, 1996

Bystrom, Olof. The Replacement Value of Wetlands in Sweden. Environmental and Resource Economics 16, 347-362. January 1, 2000

Carlsen, A.J., J. Strand, and F. Wenstop. Implicit Environmental Costs in Hydroelectric Development: An Analysis of the Norwegian Master Plan for Water Resources. Journal of Environmental Economics and Management 25, no. 3, 201-211. November 1, 1993

Carlsson, F. and M. Kataria. Assessing Management Options for Weed Control with Demanders and NonDemanders in a Choice Experiment. Working Papers in Economics no. 128, Department of Economics, Göteborg University. May 1, 2006

Carlsson, F. and O. JohanssonStenman. Willingness to Pay for Improved Air Quality in Sweden. Applied Economics 32, pp.661-669. January 1, 2000

Carlsson, F. and P. Martinsson. Do Hypothetical and Actual Marginal Willingness to Pay Differ in Choice Experiments? Application to the Valuation of the Environment. Journal of Environmental Economics and Management 41, pp. 179-192. January 1, 2001

Carlsson, F. and P. Martinsson. Willingness to Pay for Reduction in Air Pollution: A Multilevel Analysis. Environmental Economics and Policy Studies 4, 17-27. January 1, 2001

Carlsson, F., E. Lampi, and P. Martinsson. The Marginal Values of Noise Disturbances from Air Traffic: Does the Time of the Day Matter? Transportation Research Part D 9 (2004), pp. 373-385 January 1, 2004

Carlsson, F., P. Frykblom and C. J. Lagerkvist. Using Cheap Talk as a Test of Validity in Choice Experiments. Economics Letters 89, pp. 147-152. January 1, 2005

Carlsson, F., P. Frykblom and C. Liljenstolpe. Valuing Wetland Attributes: An Application of Choice Experiments. Ecological Economics 47, 95-103. January 1, 2003

Costanza, R., R. d'Arge, R. de Groot, S. Farber, M. Grasso, B. Hannon, K. Limburg, S. Naeem, R.V. O'Neill, J. 
Paruelo, R.G. Raskin, P. Sutton, and $M$. van den Belt. The Value of the World's Ecosystem Services and Natural Capital. Nature 387, 253-260. May 1, 1997. COWI Consulting Engineers and Planners AS. A Study on the Economic Valuation of Environmental Externalities from Landfill Disposal and Incineration of Waste Final Main Report. European Commission, DG Environment. October 1, 2000.

Damgaard, C. What is the Price of Noise? Danish Environmental Agency. March 1, 2002

Drake, L. The Non-market Value of the Swedish Agricultural Landscape. European Review of Agricultural Economics 19, 351-364. January 1, 1992

Dubgaard, A. Economic Valuation of Recreational Benefits from Danish Forests. The Economics of Landscape and Wildlife Conservation.

Dabbert, S., A. Dubgaard, L. Slangen, M. Whitby. Oxon, UK, CAB International. January 1, 1998

Eggert, H. and B. Olsson Heterogenous preferences for marine amenities: A choice experiment applied to water quality. Licentiate thesis, Department of Economics, School of Economics and Commercial Law, Göteborg University. April 1, 2004

Eggert, H. and B. Olsson. Heterogeneous Preferences for Marine Amenities: A choice Experiment Applied to Water Quality. Working Paper in Economics no. 126, Department of Economics, Goteborg University. January 1, 2004.

Ek, K.Valuing the Environmental Impacts of Wind Power: A Choice Experiment Approach. Thesis, Lulea University of Technology. January 1, 2002. Entec UK Limited

Economic Evaluation of Air Quality Targets for Heavy Metals. Final Report for the European Commission, January 1, 2001

Fankhauser, S. The Marginal Social Costs per Unit Emitted in the Valuing Climate Change, edited by Samuel Fankhauser. London, UK: Earthscan Publications Limited 1995. January 1, 1995

Fankhauser, S. The Economic Costs of $\mathrm{CO} 2$ Concentration Doubling in the
Valuing Climate Change, edited by Samuel Fankhauser. London, UK: Earthscan Publications Limited 1995. January 1, 1995.

Fredman, P. Values of an Endangered Species - the Case of the Whitebacked Woodpecker in Sweden. Dissertation 17, Department of Forest Economics, Swedish University of Agricultural Sciences, Umeå. January 1, 1995

Fredman, P. and L. Emmelin Wilderness Purism, Willingness to Pay and Management Preferences - A Study of Swedish Mountain Tourists. Tourism Economics 7, no. 1, pp. 5-20 January 1, 2001

Frykblom, P. Halved Emissions of Nutrients, What are the Benefits? - A Contingent Valuation Method Survey Applied to Laholm Bay Doctor's dissertation, Swedish University of Agricultural Sciences, Uppsala. May 1, 1998

Gjøsund, H. C. S. Environmental Effects of Windmills in Sandøy, a Contingent Valuation Study - Miljøkonsekvenser av vindkraft i Sandøy kommune, en verdsettingsstudie Norwegian University of Life Sciences (UMB) May 1, 2003

Granberg, M., M. Wikland, L. Nilsson and L. Hamberger. Couples' Willingness to Pay for In-Vitro Fertilization/Embryo Transfer (IVF/ET). Acta Obstetricia et Gynecologica Scandinavica. January 1, 1995

Gren, I.M. The Value of Investing in Wetlands for Nitrogen Abatement. European Review of Agricultural Economics 22 157-172. January 1, 1995.

Gren, I-M. Alternative Nitrogen Reduction Policies in the Mälar Region, Sweden. Ecological Economics, 7, pp. 159-172. January 1, 1993

Gren, Ing-Marie.,C. Folke, K. Turner, and I.J. Bateman. Primary and Secondary Values of Wetland Ecosystems Environmental and Resource Economics 4: 55-74. January 1, 1994

Gyrd-Hansen, D. Willingness to Pay for a QALY Health Economics 12: 10491060 (2003). February 1, 2003

Hagestuen, W. and K. Skogen. SocioEconomic Value of the Natural Resources of the Ullensvang State Commons - Samfunnsøkonomisk 
verdi av naturressursene i Ullensvang statsalmenning, Hardangervidda Universitetet for miljø- og biovitenskap (UMB). May 1, 1995

Halvorsen B. and K. Salensminde. Differences between Willingness-toPay Estimates from Open-Ended and Discrete Choice Contingent Valuation Methods: The Effects of Heteroscedasticity. Land Economics 74, no.2 262-282. May 1, 1998.

Halvorsen, B.Ordering Effects in Contingent Valuation Surveys Environmental and Resource Economics 8, no. 4, 485-499. December 1, 1996

Hansen, V. and C.J. Petersen. The Value of the Nuisance Related to Hog Operations by People Living Nearby - Using the Hedonic Valuation Method. The Royal Veterinary and Agricultural University (KVL). April 1, 2003

Hansesveen, H. and G. Helgås. Environmental Costs of Hydropower Development - Estimering av miljøkostnader ved en vannkraftutbygging i Øvre Otta. Norwegian University of Life Sciences (UMB). May 1, 1997

Hasler, B., C.K. Damgaard, E.H. Erichsen, J.J Jørgensen and H.E Kristoffersen. The recreational values of forest, lake and nature restoration, valuation of nature goods using the hedonic price method - De rekreative værdier af skov, sø og naturgenopretning. - værdisætning af naturgoder med husprismetoden. AKF Forlaget. November 1, 2002

Hasler, B., T.Lundhede, L. Martinsen, S. Neye and J.S Schou. Valuation of Groundwater Protection Versus Water Treatment in Denmark by Choice experiments and Contingent Valuation NERI Technical Report no. 543. June 1, 2005.

Hasund, K.P. Documentation of Three Contingent Valuation Surveys on Preservation of Landscape Elements of Agricultural Land. Småskriftserien no 107, Swedish University of Agricultural Sciences (SLU), Department of Economics, Uppsala. January 1, 1997

Hatlestad B., J. Strand, Z Tao and S. Navrud. Property Prices and Disadvantages of Nearby Roads. - Boligpriser og nærføringsulemper Statens Vegvesen Vegdirektoratet. Statens
Vegvesen -Vegdirektoratet. May 1, 2004

Heiskanen, H., E. Mäntymaa, R. Svento. Testing the Inclusiveness Insensitivity Hypothesis in Public Goods Valuation. Discussion papers in economics and business studies 9, University of Oulu. January 1, 1993

Hoen, H.F. and G. Winther. Multiple Use Forestry and Preservation of Coniferous Forests in Norway - A Study of Attitudes and Willingness to Pay. Norwegian University of Life Sciences (UMB), Department of Forestry. August 1, 1992

Hoen, H.F. and K. Veisten. A Survey Among the Users of the Oslomarka: Attitudes Toward the State and Management of the Forest Area - En undersøkelse blant brukere av Oslomarka: Synspunkter på skogtilstand og skogbehandling. Norwegian University of Life Sciences (UMB). June 1, 1994

Hokby, S. and T. Soderqvist. Elasticities of Demand and Willingness to Pay for Environmental Services in Sweden. Environmental and Resource Economics 26, 361-383. January 1, 2003

Holland, M., D. Forster, K. King, A. Haworth, P. Watkiss. Economic Evaluation of Proposals for Emission Ceilings for Atmospheric Pollutants. AEA Technology, Interim Report for DGXI of the European Commission. Analysis of Scenarios from IIASA's Seventh Interim Report. January 1, 1999

Holland, M., G. Mills, F. Hayes, A. Buse, L. Emberson, H. Cambridge, S. Cinderby, A. Terry, and M. Ashmore Economic Assessment of Crop Yield Losses from Ozone Exposure. The UNECE International Cooperative Programme on Vegetation implemented by the Centre for Ecology and Hydrology, Natural Environment Research Council under contract with the UK Department for Environment, Food and Rural Affairs (DEFRA) April 1, 2002

Horne, P.Forest Owners' Acceptance of Incentive Based Policy Instruments in Forest Biodiversity Conservation - A Choice Experiment Based Approach. Silva Fennica 40, No. 1, pp. 169-178. January 1, 2006 
Horne, P. and L. Petäjistö. Preferences for Alternative Moose Management Regimes among Finnish Landowners: A Choice Experiment Approach. Land Economics 79, No. 4, pp. 472482. November 1, 2003

Horne, P., H. Karppinen, E. Ylinen. Citizens' Opinions on Protecting Forest Biodiversity (Kansalaisten mielipiteet metsien monimuotoisuuden turvaamisesta). Chapter in "Metsänomistajien ja kansalaisten näkemykset metsäluonnon monimuotoisuuden turvaamisesta", edited by Paula Horne, Terhi Koskela, and Ville Ovaskainen. Metsäntutkimuslaitoksen tiedonantoja 933. Published by Metsäntutkimuslaitos, Vantaa. January 1, 2004

Horne, P., P. C. Boxall and W. L. Adamowicz. Multiple-use Management of Forest Recreation Sites: a Spatially Explicit Choice Experiment. Forest Ecology and Management 207, pp. 189-199. January 1, 2005

Hornsten, L. and P. Fredman. On the Distance to Recreational Forests in Sweden. Landscape and Urban Planning 51, 1-10. January 1, 2000.

Hougner, C., J. Colding and T. Söderqvist. Economic Valuation of a Seed Dispersal Service in the Stockholm National Urban Park, Sweden. Ecological Economics 59, pp. 364-374. January 1, 2006

Huhtala, A. What Price Recreation in Finland? - A Contingent Valuation Study of Non-Market Benefits of Public Outdoor Market Areas. Journal of Leisure Research 36, No. 1, pp. 2344. January 1, 2004

Huhtala, A. How Much Do Money, Inconvenience and Pollution Matter? Analysing Households' Demand for Large-Scale Recycling and Incineration. Journal of Environmental Management 55, 27-38. January 1, 1999

Israelsson, T. Valuing Natural Heritage - A Pilot Application of a Choice Experiment. Licentiate thesis, Report 122, Department of Forest Economics, Swedish University of Agricultural Sciences (SLU), Umeå. February 1,2001

Jacobsen, J.B., B.J. Thorsen, J.H. Boiesen, S. Anthon and J. Tranberg Valuation of Seven Possible National
Parks in Denmark. Forest \& Landscape, KVL. January 1, 2006

Johannesson, M. and P. Johansson. Quality of Life and the WTP for an Increased Life Expectancy at an Advanced Age. Journal of Economics 65, 219-228. January 1, 1997

Johannesson, M., and P. Johansson. To $\mathrm{Be}$, or Not to Be, That is the Question: An Empirical Study of the WTP for an Increased Life Expectancy at an Advanced Age. Journal of Risk and Uncertainty 13, 163-174. January 1, 1996

Johannesson, M., P. Johansson and K. Lofgren. On the Value of Changes in Life Expectancy Blips versus Parametric Changes. Working Paper No.152, The Economic Research Center, Stockholm School of Economics. February 1, 1997.

Johannesson, M., P. Johansson, B. Kristrom, U. Gerdtham. Willingness to Pay for Antihypertensive Therapy - Further Results

Journal of Health Economics 12, 95108. January 1, 1993.

Johansson, M.V. Valuing a Peripheral Environmental Amenity: The Swedes' Willingness to Pay for the Survival of the African Elephant. Umea Economic Studies no. 441, Umea University. January 1, 1997.

Jordal-Jørgensen, J. Samfundsmæssig værdi af vindkraft. Delrapport: Visuelle effekter og støj fra vindmøller kvantificering og værdisætning. (Social Costs of Wind Power: Partial Report of Visual Impacts and Noise from Windmills). Institute for Local Government Studies (AKF), Copenhagen, Denmark 1995 December 1, 1995

Kidholm, K. Assessing the Value of Traffic Safety Using the Contingent Valuation Technique: The Danish Survey. Paper presented at Conference on Valuing the Consequences of Road Accidents, Neuchatel, Switzerland, 1994. October 1, 1994.

Kniivilä, M. Contingent Valuation and Cost-Benefit Analysis of Nature Conservation: A Case Study in North Karelia, Finland. D. Sc. thesis summary, Research Notes 157, Faculty of Forestry, University of Joensuu. May 1, 2004. 
Kniivilä, M., V. Ovaskainen and O. Saastamoinen. Costs and Benefits of Forest Conservation: Regional and Local Comparisons in Eastern Finland. Journal of Forest Economics 8, pp. 131-150. January 1, 2002.

Kosenius, A.-K. Estimating the Benefit from Algal Bloom Reduction - an Application of Contingent Valuation Method. Master's thesis, Department of Economics and Management, University of Helsinki. May 1, 2004

Kristofersson, D. and S. Navrud. Can Use and Non-Use Values be Transferred Between Countries? European Association of Environmental and Resource Economics 13th Annual Conference, Budapest Hungary, June 25th to 28th 2004. June 1, 2004

Kristroem, B.

A Non-Parametric Approach to the Estimation of Welfare Measures in Discrete Response Valuation Studies. Land Economics, 66 (2), 135-139. January 1, 1990

Kriström, B. Spike Models in Contingent Valuation. American Journal of Agricultural Economics 79, no. 3, 1013-1023. August 1, 1997

Kuuluvainen, J., E. Lehtonen, E. Pouta, M. Rekola, C.-Z. Li. Economic Valuation of Forest Conservation Benefits in Southern Finland and Pohjanmaa. Preliminary Results. (Etelä-Suomen ja Pohjanmaan metsien suojelun hyötyjen taloudellinen arvottaminen. Alustavia tuloksia.) Reports 22, Department of Forest Economics, University of Helsinki. ISBN 952-10-0588-2. January 1, 2002

Kvendokk S. and K. E. Rosendahl. CO2 Mitigation Costs and Ancillary Benefits in the Nordic Countries, the UK and Ireland: A Survey. First author is affiliated with Ragnar Frisch Centre for Economic Research. October 1, 2000

L. Tyrvainen. Economic Valuation of Urban Forest Benefits in Finland. Journal of Environmental Management, 62 p. 75-92. January 1, 2001

Ladenburg, J and L. Martinsen. Danish Consumers' Willingness to Pay for Certified Wood Products - A Contingent Ranking Study. Samfundsvidenskabelige 14, Social Science Series, Papers from Unit of Economics, Dan- ish Research Institute of Food Economics, Royal Veterinary and Agricultural University, Denmark. January 1,2004

Ladenburg, J., A. Dubgaard, L. Martinsen and J. Tranberg. Economic Valuation of the Visual Externalities of Offshore Wind Farms. Food and Resource Economic Institute. January 1, 2005

Lagerkvist, C. J., F. Carlsson and D. Viske. Swedish Consumer Preferences for Animal Welfare and Biotech: A Choice Experiment. AgBioForum (The Journal of Agrobiotechnology Management and Economics), 9(1):51-58. January 1, 2006

Laitila, T. and A. Paulrud. Anglers valuation of water regulation dam removal for restoration of angling conditions at Storsjö Kapell. IFTET 2006 Portsmouth Proceedings. January 1, 2006

Laitila, T. and A. Paulrud. A MultiAttribute Extension of DiscreteChoice Contingent Valuation for Angling Site Characteristics. Journal of Leisure Research, Vol. 38, No. 2, pp. 133-142. January 1, 2006

Lehtonen, E., J. Kuuluvainen, E. Pouta, M. Rekola and L. Chuan-Zhong. Non-Market Benefits of Forest Conservation in Southern Finland. Environmental Science and Policy 6, 195204. January 1, 2003

Lehtonen, E., J. Kuuluvainen, V. Ovaskainen, E. Pouta, M. Rekola. Influence of Logit Model Assumptions on Estimated Willingness to Pay for Forest Conservation in Southern Finland. Reports 35, Department of Forest Economics, University of Helsinki, ISBN 952-10-2291-4. January 1, 2005

Leidal, K. Valuation of a Recreational Area on the City Rim - Verdsetting av et bynært rekreasjonsområde. Norwegian University of Life Sciences (UMB). May 1, 1996

Leksell, I. and A. Rabl. Air Pollution and Mortality: Quantification and Valuation of Years of Life Lost. Risk Analysis 21, No. 5, 843-856. January 1, 2001

Li, C-Z and P. Fredman. On Reconciliation of the Discrete Choice and OpenEnded Responses in Contingent Valuation Experiments. Doctoral Dis- 
sertation, Umeå Economic Studies No. 341, Department of Economics, University of Umeå, Sweden. June 1, 1994

Li, C-Z., J. Kuuluvainen, E. Pouta, M. Rekola, O. Tahvonen. Using Choice Experiments to Value the Natura 2000 Conservation Programs in Finland. Environmental \& Resource Economics 29, pp. 361-374. January 1, 2004

Lienhoop, N. and D. MacMillan. Valuing Wilderness in Iceland: Estimation of WTA and WTP Using the Market Stall Approach to Contingent Valuation. Land Use Policy, article in press. January 1, 2006

Lindberg, K., and P. Fredman. Destination Attributes and Predicted Market Shares: A Choice Experiment of Snowmobilers and Cross-Country Skiers. WP 2004:02, European Tourism Research Institute. January 1, 2004

Lindberg, K., T. Heldt and P. Fredman. The Value of Reducing Recreation Conflict: A Choice Experiment Evaluation of Snowmobiler-Skier Conflict. Chapter in doctoral dissertation, Economic Studies 86, Department of Economics, Uppsala University, Sweden. June 1, 2005

Lindberg, K., T.D. Andersson and B.G.C. Dellaert. Tourism Development - Assessing Social Gains and Losses. Annals of Tourism Research 28, no. 4, pp. 1010-1030. January 1, 2001

Lindhjem, H. 20 Years of Stated Preference Valuation of Non-Timber Benefits from Fennoscandian Forests: A Meta-Analysis. Norwegian University of Life Sciences (UMB). September 1, 2006

Lindhjem, H. Willingness to Pay for Improved Water Quality of Steinsfjorden - Betalingsvillighet for en bedret vannkvalitet i Steinsfjorden. The University of Oslo (UiO). May 1, 1998

Luktvasslimo, S. and O. M. A. Berg. Big Carnivores and Sheep, an Economic Analysis - Rovdyr og sau, en $ø$ konomisk analyse. Universitet for Miljø og Biovitenskap (UMB). May 1, 1998

Lundhede, T., B. Hasler and T. Bille. Valuing the Reconstruction of Nature and Cultural Heritage in Store Åmose, Vestsjælland. Danish Forest and Nature Agency. August 1, 2005

Magnussen, K. and O. Bergland. Valuing Environmental Toxins in Water - Verdsetting av miljøgifter i vann. Stiftelsen Østfoldforskning. December 1, 1996

Magnussen, K. and S. Navrud. Valuation of Reduced Pollution to the North Sea - Verdsetting av redusert forurensing til Nordsjøen. Norwegian Agricultural Economics Research Institute (NILF). March 1, 1992

Magussen K.,O. Bergland and S. Navrud. Transfer of Benefit Estimates: The State of Norway, and Tests of Water Quality- Overføring av nytteestimater: Status i Norge og utprøving knyttet til vannkvalitet. Del II Utprøving knyttet til vannkvalitet (original report is in Norwegian only). NIVA Norwegian Institute for Water Research (Norsk institutt for vannforskning). November 1, 1995

Markowska, A. and T. Zylicz. Costing an International Public Good: The Case of the Baltic Sea. Ecological Economics 30, 301-316. January 1, 1999

Mattsson, L. Hunting in Sweden: Extent, Economic Values and Structural Problems. Scandinavian Journal of Forest Research 5:563-573. January 1, 1990

Mattsson, L. and C. Li. How do Different Forest Management Practices Affect the Non-timber Value of Forests?- an Economic Analysis. Journal of Environmental Management 42, 79-88. January 1, 1994

Moisseinen, E. Contingent Valuation The Case of the Saimaa Seal. Publications in Social Sciences 28, University of Joensuu. January 1, 1997

Mäntymaa E. Valuing Environmental Benefits Using the Contingent Valuation Method (Ympäristöhyötyjen arviointi contingent valuation menetelmällä). Research Reports 109, Research Institute of Northern Finland, University of Oulu. January 1, 1993

Mäntymaa, E. Pennies from Heaven? A Test of the Social Budget Constraint in a Willingness to Accept Compensation Elicitation Format. Journal of 
Forest Economics 5, no. 1, pp. 169192. January 1, 1999

Mäntymaa, E., M. Mönkkönen, J. Siikamäki, R. Svento. Estimating the Demand for Biodiversity - Vagueness Band and Open-Ended Questions in Proceedings: Risk and Uncertainty in Environmental and Resource Economics, edited by van Ierland, E.C., H.P. Weikard, J. Wesseler. Wageningen University: Environmental Economics and Natural Resources Group. June 1, 2002

Navrud S. Environmental Costs of Hydropower, Second Stage - Miljøkostnadsprosjektet Trinn 2. EBL report 181- 2004. July 1, 2004

Navrud, S. Economic Benefits of a Program to Reduce Transportation and Community Noise - a Contingent Valuation Study. Norwegian University of Life Sciences (UMB). August 1,2000

Navrud, S. Linking Physical and Economic Indicators of Environmental Damages. Chapter 6 in C. L. Spash and S. McNally (eds.) 2001: Case Studies in Ecological and Environmental Economics. John Wiley \& Sons Ltd. January 1, 2001

Navrud, S. Socio-economic Efficiency of Liming Lake Vegår - Samfunnsøkonomisk lønnsomhet av å kalke Vegår. Directorate for Nature Management (DN). July 1, 1993

Navrud,S., Y. Trædal, A.Hunt, A. Longo, A. Greßmann, C. Leon, R.E. Espino, R.Markovits-Somogyi and F. Meszaros. Economic values for key impacts valued in the Stated Preference surveys. HEATCO - Developing Harmonised European Approaches for Transport Costing and Project Assessment. Deliverable four. Contract No. FP6-2002-SSP1/502481. European Commission. February 1, 2006

Nielsen, F.S. and L.I. Vestby. The Recreational Value of Trout Sports Fishing in Dokkavassdraget - Rekreasjonsverdien av fritidsfisket etter ørret i øvre deler av Dokkavassdraget og holdninger til fiskestelltiltak. Norwegian University of Life Sciences (UMB). May 1, 1995

Nordahl, E. A Contingent Valuation Study of Environmental Impacts of Windmill Development of Smøla -
Miljøkostnader av vindkraftutbygging på Smøla. Norwegian University of Life Sciences (UMB). August 1, 2000

Nunes, P.A.L.D., J.C.J.M. van den Bergh. Economic Valuation of Biodiversity: Sense or Nonsense. Ecological Economics 39, no. 2 203-222. November 1, 2001

Olsen, S.B. and T. Lundhede. Recreational Values in Near-natural Silviculture - An Economic Valuation of Forest Characteristics using Discrete Choice Experiment. The Royal Veterinary and Agricultural University (KVL). March 1, 2005

Olsen, S.B., J. Ladenburg, M.L. Petersen, U. Lodrup, A.S. Hansen and A. Dubgaard. Motorways versus Nature. A Welfare Economic Valuation of Impacts. Environmental Assessment Institute. December 1, 2005

Olsson, B. Stated Preferences for Improved Cod Stocks in Sweden. Licentiate thesis, Department of Economics, School of Economics and Law, Göteborg University. April 1, 2004

Olsthoorn, X., M. Amann, A. Bartonova, J. Clench-Aas, J. Cofala, K. Dorland, C. Guerreiro, J. Fr. Henriksen, H. Jansen and S. Larssen. Cost Benefit Analysis of European Air Quality Targets for Sulphur Dioxide, Nitrogen Dioxide and Fine and Suspended Particulate Matter in Cities. Environmental and Resource Economics 14, 333-351. January 1, 1999 Ovaskainen, V. and M. Kniivilä. Consumer Versus Citizen Preferences in Contingent Valuation: Evidence on the Role of Question Framing. The Australian Journal of Agricultural and Resource Economics 49, pp. 379-394. January 1, 2005

Ovaskainen, V., J. Mikkola, E. Pouta. Estimating Recreation Demand with On-site Data: An Application of Truncated and Endogenously Stratified Count Data Models. Journal of Forest Economics 7, no. 2, pp. 125144. January 1, 2001

Ovaskainen, V., P. Horne, J. Mikkola. The Recreational Value of Hiking Areas and National Parks (Retkeilyalueiden ja Kansallispuistojen Virkistyskäytön Arvo). Chapter from: Metsän eri käyttömuotojen arvottaminen ja yhteensovittaminen (Finnish), editors J. Kangas and A. 
Kokko, Metsäntutkimuslaitoksen tiedonantoja 800. January 1, 2001

Parkkila K. Estimating the Willingness to Pay for Catch Improvements in the River Simojoki - An Application of Contingent Valuation Method (Simojoen lohen saalismäärän lisääntymisen taloudellinen arviointi contingent valuation-menetelmällä). Master's thesis, Department of Economics and Management, University of Helsinki. November 1, 2005

Paulrud, A. and T. Laitila. Valuation of Management Policies for SportFishing on Sweden's Kaitum River. Journal of Environmental Planning and Management, 47(6): 863-879. November 1, 2004

Pedersen, H. The Recreational Value of Sports Fishing in Dokka/Etna for the 1993/1994 Season - Rekreasjonsverdien av fisket i Dokka/Etna for 1993og 1994-sesongen. Norwegian University of Life Sciences (UMB). May 1, 1995

Persson, U. and M. Cedervall. The Value of Risk Reduction: Results of a Swedish Sample Survey. Swedish Institute of Health Economics, working paper 1991:6. February 1, 1991

Pouta, E. Attitude and Belief Questions as a Source of Context Effect in a Contingent Valuation Survey. Journal of Economic Psychology 25, pp. 229242. January 1, 2004

Pouta, E. Sensitivity to Scope of Environmental Regulation in Contingent Valuation of Forest Cutting Practices in Finland. Forest Policy and Economics 7, 539-550. January 1, 2005

Pouta, E., M. Rekola. Finnish Citizens' Willingness to Pay for Forest Conservation: a Meta-analysis (Suomalaisten maksuhalukkuus metsiensuojelusta: meta-analyysi). Metsätieteen aikakauskirja 2, pp. 243-255. January 1, 2006

Pouta, E., M. Rekola, C.Z. Li, J. Kuuluvainen, O. Tahvonen. Using Choice Experiments to Value Natura 2000 Nature Conservation Programs in Finland. Department of Economics, University of Dalarna, Sweden. January 1, 2001

Pouta, E., M. Rekola, J. Kuuluvainen, C.-Z. Li, O. Tahvonen. Willingness to Pay in Different Policy-Planning Methods: Insights into Respondents'
Decision-Making Processes. Ecological Economics 40, 295-311. January 1, 2002

Pouta, E., M. Rekola, J. Kuuluvainen, O. Tahvonen, C.-Z. Li. Contingent valuation of the Natura 2000 nature conservation programme in Finland. Forestry 73, No. 2, pp. 119-128. January 1, 2000

Ready, R., S. Navrud, B. Day, R. Dubourg, F. Machado, S. Mourato, F. Spanninks, M.X.V. Rodriquez. Benefit Transfer in Europe: How Reliable are Transfers Between Countries? Environmental and Resource Economics 29,no. 1, 67-82. September 1 , 2004

Ready, R.C., S. Navrud, and W.R. Dubourg. How do Respondents with Uncertain Willingness to Pay Answer Contingent Valuation Questions? Department of Economics and Social Sciences, Agricultural University of Norway, As, Norway. January 1, 1999

Rekola, M., and E. Pouta. Public Preferences for Uncertain Regeneration Cuttings: a Contingent Valuation Experiment Involving Finnish Private Forests. Forest Policy and Economics, Article in Press. January 1, 2004

Rekola, M., E. Pouta, J. Kuuluvainen, O. Tahvonen, C.-Z. Li. Incommensurable Preferences in Contingent Valuation: the Case of Natura 2000 Network in Finland. Environmental Conservation 27, No. 3, pp. 260-268. January 1, 2000

RIVM, EFTEC, NTUA and IIASA in association with TME and TNO. Technical Report on Biodiversity. RIVM report 481505019. November 1, 2000

S. Fankhauser. The Costs of Adaptation: The Case of Sea Level Rise in the Valuing Climate Change, edited by Samuel Fankhauser. London, UK: Earthscan Publications Limited 1995. January 1, 1995

Saelensminde, K. Stated Choice Valuation of Urban Traffic Air Pollution and Noise. Transportation Research Part D, 4, 13-27. January 1, 1999

Sandsbråten, L. Valuing Environmental Goods in Oslomarka - Verdsetting av miljøgoder i Oslomarka. Norwegian University of Life Sciences (UMB). May 1, 1997 
Sandstrom, M. Recreational Benefits from Improved Water Quality: A Random Utility Model of Swedish Seaside Recreation. Stockholm School of Economics, Economics Research Institute, Working Paper No. 121. August 1, 1996

Siikamäki, J. Discrete Choice Experiments for Valuing Biodiversity Conservation in Finland. Dissertation, Department of Environmental Sciences and Policy, University of California, Davis. January 1, 2001

Skagestad, E.C. Recreation and Forestry - Friluftsliv og skogbruk. Norwegian University of Life Sciences (UMB). May 1, 1996

Soderqvist, T. Contingent Valuation of a Less Eutrophicated Baltic Sea. Beijer Discussion Paper Series No. 88, Beijer International Institute of Ecological Economics, The Royal Academy of Sciences, Stockholm.ISSN 1102-4941. January 1, 1996

Soderqvist, T. Natural Resources Damage from Chernobyl: Further Results. Environmental and Resource Economics 16, 343-346. January 1, 2000

Söderqvist, T. Property Values and Health Risks: The Willingness to Pay for Reducing Residential Radon Radiation. Scandinavian Housing and Planning Research 12, pp. 141-153. January 1, 1995

Soderqvist, T. and H. Scharin. The Regional Willingness to Pay for a Reduced Eutrophication in the Stockholm Archipelago. Discussion paper no. 128, Beijer International Institute of Ecological Economics, The Royal Swedish Academy of Sciences. January 1,2000

Soini, E. and P. Horne. Status Quo Bias in Choice Experiment Method - A Case Study of Forest Owners' Acceptance of Biodiversity Conservation Contracts. Paper presented at the 7th International BIOECON Conference on Economics and the Analysis of Ecology and Biodiversity, Kings College Cambridge, 20-21 September 2005. September 1, 2005

Soutukorva, Å. The Value of Improved Water Quality - A Random Utility Model of Recreation in the Stockholm Archipelago. Beijer Discussion Paper Series No. 135, Beijer International Institute of Ecological Econom- ics, The Royal Swedish Academy of Sciences. May 1, 2005

Sterner, T. and H. Bartelings. Household Waste Management in a Swedish Municipality: Determinants of Waste Disposal Recycling and Composting. Environmental and Resource Economics 13, 473-491. January 1, 1999

Sundqvist, T. Quantifying Household Preferences over the Environmental Impacts of Hydropower in Sweden: A Choice Experiment Approach. Dissertation, 2002:26, Luleå University of Technology, Sweden. August 1, 2002

Svedsater, H. Contingent Valuation of Global Environmental Resources: Test of Perfect and Regular Embedding. Journal of Economic Psychology 21 (2000) 605-623. January 1, 2000

Svento R. Some Notes on Trichotomous Choice Discrete Valuation"'"'Environmental and Resource Economics 3, pp. 533-543. January 1, 1993

Termansen, M., C.J. McClean, and R. Scarpa. Economic Valuation of Danish Forest Recreation Combining Mixed Logit Models and GIS. Paper presented at the Association of Environmental and Resource Economists Conference. Budapest, Hungary. June 1, 2004

Tervonen, J, E. Alasaarela and R. Svento. Household Water Quality and Consumer Welfare: An Application to the City of Oulu. Aqua Fennica 24,1, pp. 83-92. January 1, 1994

Toivonen, A.L., E. Roth, S. Navrud, G. Gudbergsson, H. Appelblad,

B.Bengtsson, and P.Tuunainen. The Economic Value of Recreational Fisheries in Nordic Countries. Fisheries Management and Ecology 11, pp. 1-14. January 1, 2004

Travainen, L. Economic Value of Urban Forests: Comparison of Economic Estimates. The Living Forest: Non Market Benefits of Forestry Proceedings of an International Symposium on Non-market Benefits of Forestry, edited by Charles Stewart Roper and Andy Park. June 1, 1996

Tronstad, A. Valuation of the Cultural Landscape - Holdninger og betalingsvillighet for jordbrukslandskapet 
Norwegian University of Life Sciences (UMB). September 1, 1993

Turner, R.K., S. Georgiou, I-M. Gren, F. Wulff, S. Barrett, T. Soderqvist, I.J. Bateman, C. Folke, S. Langaas, T. Zylicz, K-G. Maler, and A. Markowska. Managing Nutrient Fluxes and Pollution in the Baltic: An Interdisciplinary Simulation Study. Ecological Economics 30: 333-352. January 1, 1999

Tyrvainen, L. and H. Vaananen. The Economic Value of Urban Forest Amenities: An Application of the Contingent Valuation Method. Landscape and Urban Planning 43, 105118. January 1, 1998

Tyrvainen, L., and A. Miettinen. Property Prices and Urban Forest Amenities. Journal of Environmental Economics and Management 39, 205223. January 1,2000

Tyrväinen, L. The Amenity Value of Urban Forest; an Application of the Hedonic Pricing Method. Landscape and Urban Planning 37, pp. 227-222. January 1, 1997

Wahl, T.S. Valuing Municipal Open Areas in Oslo - Verdsetting av kommunale friområder i Oslo. University of Oslo (UiO). August 1, 1997

Vainio, M. Traffic Noise and Air Pollution. Valuation of Externalities with Hedonic Price and Contingent Valuation Methods. Ph. D. dissertation. Helsinki School of Economics and Business Administration, Acta Universitatis Oeconomicae Helsingiensis, A-102, ISBN 951-702-799-0. January 1,1995

Veisten K. and S. Navrud. Contingent Valuation and Actual Payment for Voluntarily Provided Passive-Use Values: Assessing the Effect of an Induced Truth-Telling Mechanism and Elicitation formats. Applied Economics, 38, 735-756. April 1, 2006

Veisten, K., H.F. Hoen, S. Navrud, J. Strand. Scope Insensitivity in Contingent Valuation of Complex Environmental Amenities. Norwegian University of Life Sciences (UMB). May 1, 2003

Welsch, H. Environment and Happiness: Valuation of Air Pollution in Ten European Countries. German Institute for Economic Research. July 1, 2003
Wilhelmsson, M. Valuation of TrafficNoise Abatement. Journal of Housing and the Built Environment (2005). January 1, 2005

Wilhelmsson, M. The Impact of Traffic Noise on the Values of Single-Family Houses. Dissertation, Memorandum 5:50, Department of Real Estate and Construction Management, Royal Institute of Technology, Stockholm. June 1, 2000

Wilkstrom, D. Willingness to Pay for Sustainable Coffee: A Choice Experiment Approach. Master's Thesis, Lulea University of Technology. January 1, 2003

Winslott Hiselius, L. Using Choice Experiments to Assess People's Preferences for Railway Transports of Hazardous Materials. Risk Analysis 25, no. 5, pp. 1-16. January 1, 2005

Zandersen, M and R. Tol. A Metaanalysis of Forest Recreation Values in Europe. Working Paper no. FNU86, Research Unit Sustainability and Global Change. August 1, 2005

Zandersen, M., M. Termansen and F. S. Jensen. Benefit Transfer Over Time of Ecosystem Values: The Case of Forest Recreation. Working Paper no. FNU-61, Danish Centre For Forest, Landscape and Planning. February 1, 2005

Zethraeus, N. and P. Johansson. Willingness to Pay for Hormone Replacement Therapy. Working Paper Series in Economics and Finance no. 214, Department of Economics, Stockholm School of Economics. December 1, 1997 